\title{
Feeling the blues
}

\section{Moral hazard and debt dilution in Eurobonds before 1914}

\author{
Rui Pedro Esteves ${ }^{\dagger}$ \\ Ali Coşkun Tunçer *
}

March 2016

\begin{abstract}
Debt mutualisation through Eurobonds has been proposed as a solution to the Euro crisis. Although this proposal found some support, it also attracted strong criticisms as it risks raising the spreads for strong countries, diluting legacy debt and promoting moral hazard by weak countries. Because Eurobonds are a new addition to the policy toolkit, there are many untested hypotheses in the literature about the counterfactual behaviour of markets and sovereigns. This paper offers some tests of the issues by drawing from the closest historical parallel-five guaranteed bonds issued in Europe between 1833 and 1913. The empirical evidence suggests that contemporary concerns about fiscal transfers and debt dilution may be overblown, whilst creditors' moral hazard may be as much of a problem as debtors'.
\end{abstract}

JEL Codes: F34, H63, H77, N24, N44

Keywords: Eurobonds, Debt Mutualisation, Debt Dilution, Moral Hazard, Pre-1913

The authors thank Marc Flandreau, Kris Mitchener, Kim Oosterlinck, Vincent Bignon and an anonymous referee for detailed comments. The paper has also benefited from discussion with the participants in the First CEPR Economic History Symposium in Perugia, the $10^{\text {th }}$ EHES Conference in London, the $8^{\text {th }}$ Conference of the SEEMHN in Amiens, the $33^{\text {rd }}$ Conference of the APHES in Braga, the 2015 Meeting of the American Economic Association in Boston and seminars at the Banque de France, the University of Geneva, the New University of Lisbon and Humboldt University. The usual disclaimer applies. The research leading to these results has received funding from the People Programme (Marie Curie Actions) of the European Union's Seventh Framework Programme FP7/2007-2013/ under REA grant agreement nº 608129.

\footnotetext{
† University of Oxford, Economics Department, Manor Road, Oxford OX13UQ; rui.esteves@economics.ox.ac.uk

‡ University College London, History Department, Gower Street, London WC1E6BT; a.tuncer@ucl.ac.uk
} 


\section{Introduction}

The European sovereign debt crisis, which has been affecting some of the heavily indebted member states of the European Union since 2008, has casted doubts on the long-term sustainability of the European Monetary Union (EMU). Different proposals to tackle the crisis include introducing structural reforms in programme countries, higher inflation targets for the ECB and restructuring EU institutions along the lines of stronger federalism. An important line of this debate focuses on the debt mutualisation through the issue of "Eurobonds". Having appeared under different labels and guises, the Eurobonds proposal, in essence, recommends that EMU countries pool all or a fraction of their debts. This would presumably reduce borrowing costs for member states and stabilise the European debt market. Although this proposal found some support, it also attracted strong criticisms for its possible caveats, particularly for its potential for generating moral hazard and diluting the outstanding debt stock.

Compared to other tried solutions for fiscal crises, such as debt restructuring or default, inflation and devaluation, and stabilisation plans from multilaterals, there is precious little evidence on the potential effectiveness of the Eurobonds proposal. The bailout and recapitalisation programmes organised since 2010 offer some suggestions of how Eurobonds could fare in the market, particularly after the reduction in mid-2011 of the interest paid by programme countries to close to the effective cost of funding of multilaterals. However, it is questionable whether the relatively short experience with these loans is a good estimate of the consequences of debt mutualisation for the future of European financial stability. The debate has therefore been mainly informed by untested hypotheses about the behaviour of financial markets and sovereigns after the issue of Eurobonds (Claessens 2012).

This paper aims to contribute to this debate by drawing on the history of five guaranteed bonds issued before 1914. Somewhat ironically, these operations started with a Greek loan in 1833, which can arguably be considered the first Eurobond in history. The bonds we study were issued with the 
guaranty of other sovereigns, usually a combination of the great powers of the time (Britain, France, Germany and Russia) and were perceived by the market as instances of debt mutualisation, unlike the current European programme bonds (EFSF, EFSM and ESM). Perhaps because of the risks involved for the guarantors, these loans were seldom raised and often only after overcoming considerable political opposition within the guarantor countries themselves. After the first Greek loan, there were only four other guaranteed loans issued in our period of study - for Turkey in 1855, Egypt in 1885, China in 1895, and Greece again in 1898. Despite the significant differences between current and pre-1914 international financial architecture, we argue that the guaranteed bonds constitute the most relevant historical examples of debt mutualisation. Consequently, we borrow the current terminology in distinguishing between 'blue bonds' (mutualised debt) and 'red bonds', the exclusive responsibility of each sovereign (Delpla and von Weizsäcker 2010).

We use the long historical record of these five loans to address three main questions - how the introduction of guaranteed bonds impacted existing creditors, how they were initially received by the markets, and how markets priced guaranteed debt relative to the other bonds of the assisted countries. The first two questions focus on the short-time horizon around the announcement and flotation of guaranteed bonds. By using an original dataset of daily market prices, we investigate the direct dilution of previous claims on the sovereign, which depended on the relative shares of 'blue' (guaranteed) and 'red' (non-guaranteed) bonds, seniority dispositions, possible write-downs of existing debts, liquidity of the new issues, and, when included, the benefits from foreign-imposed conditionality. We also compare the yields of guaranteed bonds to the marginal costs of funding of the guarantors. The third question has to be addressed over longer time horizons. In this part of the paper, we quantify the evolution of the spreads of guaranteed bonds relative to other nonguaranteed domestic bonds, and investigate the relation between the yields of guaranteed bonds, their non-guaranteed cousins, and their avuncular guarantors. These spreads are informative of the structural impact of these debt relief operations on the fiscal positions of the recipient nations and 
should help with addressing the contemporary criticisms about debtors' moral hazard from the issue of Eurobonds.

Our paper also relates to the literature on non-sovereign borrowing and foreign financial intervention in the pre-1914 period. Two of the countries under study here (China and Egypt) were under a status of informal colonial dependency from outside Powers. Nevertheless, we show that guaranteed bonds of these countries were perceived differently in the market from other colonial issues, in that they were not priced entirely on the fiat of the colonial power. Colonial issues were more than guaranteed by the coloniser, as the latter reserved complete control over colonial finances (Accominotti et al. 2010, Chavaz and Flandreau 2015). A different category of bonds were those issued under the financial (and sometimes political) control of foreign creditors, where the latter controlled the domestic sources of revenue set aside to service the foreign debt (Mitchener and Weidenmier 2010, Tuncer 2015). Two of the case studies in this paper (Egypt in 1885 and Greece in 1898) fall in this category. Despite the existence of international financial control in Egypt and Greece, their guaranteed bond issues were treated differently in the market. International financial control increased the credibility of each sovereign through the direct transfer of revenues to foreign creditors; however, it did not guarantee any repayments as in the case of guaranteed bonds. Furthermore, there was not necessarily an overlap between the list of guarantors and the powers involved in financial control. In the paper, we elaborate on these two different cases of infringement of sovereignty through colonial issues and international financial control.

The next section describes and compares the current proposals for the issuance of Eurobonds with the corresponding debate in the nineteenth century, emphasising the similarities between the two. Section 3 provides a simple framework to think about the relation between debt dilution and fiscal discipline. Section 4 contains the empirical analysis split into two parts. In a first part we use structural breakpoint methods to identify the short-run impact of the introduction of guaranteed bonds on the previous debt stock. In the second part we investigate the pricing relations between 
guaranteed and non-guaranteed bonds with the help of factor analysis and dynamic panel VARs. A conclusion follows.

\section{Eurobonds: policy and history}

\subsection{Varieties}

Since September 2008 a half-dozen plans to implement some version of Eurobonds emerged in the literature from academics, trade associations and official organisations. These diverge on several levels, especially on the questions of coverage and guaranties. The majority of plans recommend that Eurobonds cover only partially the funding requirements of participating countries. ${ }^{1}$ Delpla and von Weizsäcker (2010) recommend that 'blue bonds,' jointly issued, be capped at a fraction of GDP (possibly $60 \%$ as in the Maastricht criteria), whereas any excess debt remains the responsibility of individual countries that continue to issue their own 'red' bonds. ${ }^{2}$ Another consideration is the legal nature of the guaranty. If the guaranty is only several, each guarantor state is expected to take the responsibility for only a share of the loan in case of default, whereas with a joint guaranty participant countries are individually liable for the full amount. Some proposals require joint responsibility for common bonds, despite its likely violation of the no-bailout clause of the European treaties (Delpla and von Weizsäcker 2010, Jones 2010, Barclays Capital 2011, Favero and Missale 2011). Precisely because of this, other authors consider that several guaranties would be enough (De Grauwe and Moesen 2009, Brunnermeier et al. 2011).

Although the discussion over Eurobonds has taken place with very limited historical reference, the pre-1914 guaranteed bonds share striking parallels. In Table 1, we summarise the main features

\footnotetext{
${ }^{1}$ The exceptions are Dübel (2011) and Beck, Wagner and Uhlig (2011) and Brunnermeier et al. (2011), who propose to swap the entirety of existing debt into two tranches of joint bonds.

${ }^{2}$ Bofinger et al. (2011) propose the opposite, i.e. mutualising only the excess debt shares.
} 
of the five guaranteed loans that we study here, namely, the guarantors' characteristics (identity and cost of funding), the causes behind each bond and possible conditionality attached, and the properties of the guaranteed bonds (nominal value, coupon and yield at issue), as well as the previous debt stock of the borrowing country.

\section{Table 1 here}

To begin with, the markets interpreted these bonds as forms of debt mutualisation between the guarantor and the recipient nations. The London Stock Exchange's (LSE) official list was very clear about this since it grouped the guaranteed bonds with the British government bonds in a seeming recognition that both classes of bonds were direct claims on the British taxpayer. ${ }^{3}$ In terms of guaranties, the only bond floated with a several guaranty was the first Greek loan of 1833. All other operations involved joint guaranties and that probably had to do with the lessons from the first Greek operation, as we explain below. Apart from the guaranties, the five bonds under study were issued with explicit seniority clauses over all previous debt.

In 1833 , Greece received guaranteed bonds worth $57 \%$ of its previous loans. Greece again in 1898 was granted guaranteed bonds corresponding to $19 \%$ of its outstanding debt. However, as the guaranteeing powers imposed a $61 \%$ haircut, the share of guaranteed bonds rose to close to half of the new debt (Esteves 2013). These fractions were even higher in the cases of Turkey in 1855 and China in 1895 and are comparable to the contemporary projects for the issue of Eurobonds. Applying Delpla and von Weizsäcker's (2010) proposal of issuing blue bonds up to 60\% of GDP would imply, in 2011, a stock of Eurobonds worth $35 \%$ of the pre-existing Greek debt, and more than $50 \%$ of the Irish or Portuguese ones.

\subsection{Objectives}

\footnotetext{
${ }^{3}$ This was not the case for the loans of British colonies, which were listed separately.
} 
In the recent debate, the most obvious beneficiaries from Eurobonds are the 'weak countries' that faced a widening of spreads. Either through pooling, diversification, seniority or credit enhancements, the new Eurobonds are expected to pay lower yields than most national debts. This is especially important during financial crises, when markets can no longer price risk efficiently (Delors 1989). 'Strong countries' with normal access to wholesale markets would also benefit indirectly, and perhaps even directly. The main indirect benefits are financial stability and greater efficiency in monetary policy transmission within the Eurozone, once the home bias in banking portfolios of sovereign debt is replaced with the issue of a safe(r) asset on which the whole financial system can base itself. Jones (2010), Brunnermeier et al. (2011) and Varoufakis and Holland (2011) also consider that Eurobonds would allow recycling surpluses within the Eurozone without destabilising current accounts. Direct benefits would come from liquidity gains and a greater international role for the Euro from the joint issue of a benchmark asset.

Before 1914, political and financial stability were closely associated -especially in regions where the interests of foreign powers clashed, such as the Eastern Mediterranean and China. Hence, the relationship between guarantors and debtors was heavily determined by political considerations of the guarantor states, which were one or a combination of the great powers of the time: Britain, France, Germany and Russia. Therefore, it is not surprising that all guaranteed bonds are linked to some sort of political turmoil (Jeze 1924, Viner 1928). The bond issued in 1833 in support of the Greek independence from the Ottomans was the first example of this involvement by European powers. The Greco-Turkish war of 1897 was also the cause for the 1898 Greek loan, similar to the Crimean War for the 1855 Ottoman loan, and the Sino-Japanese war for the 1895 Chinese loan. Even for the Egyptian loan of 1885 the main reason was the payment of war expenditures and associated indemnities from the Urabi revolt. In other words, guaranteed bonds were the financial counterpart of the political settlement of conflicts in sensitive areas for the great powers. Strategic considerations have been equally adumbrated in the case of the recent negotiations for the third Greek bailout, while Eurobonds may be seen by some as a first step to consolidate fiscal federalism 
and, ultimately, the European project of political union (Serbos 2015, Tsebelis 2015). Nevertheless, the connection between financial insolvency, debt assistance and political intervention was more obvious in the nineteenth century. This aspect of the pre-1914 sovereign debt market helps us with identifying the effect of guaranteed loans. On the one hand, it was very unlikely that countries started losing wars to solve an unsustainable financial position by receiving external financial assistance. On the other, the wars in question were started for reasons exogenous to the financial strains of the belligerents. Consequently, we can take the market's reaction to the announcement of these financial operations as the causal effect of the guaranty on the assisted country's financial position.

The identification of this effect would be more complicated today because it is generally understood that the convergence in sovereign bond yields after 1999 was driven by the markets' expectation that the debt of the Eurozone members was under a blanket guaranty given the perceived cost of a 'first-exit' to the credibility of the EMU (Bernoth et al. 2012, Aizenman et al. 2013, Beirne and Fratzscher 2013 and Ghosh et al. 2013, Eijffinjer et al. 2015). The developments since the Eurozone crisis have both qualified and confirmed these expectations. The initial widening of the spreads of highly indebted Eurozone members duly led to sovereign crises. But these did not end in defaults and were instead solved through the organised bailout programmes. Later, the ECB's direct intervention in the markets via OMTs and, more recently, QE has been credited with stabilising the market for sovereign debt allowing almost all countries (with the exception of Greece) to return to the market on their own. Trying to identify the likely contribution of Eurobonds in this complex policy setting is therefore less clear than in the relatively straightforward historical case studies considered in this paper.

\subsection{Caveats}


There is considerable scepticism in the literature on the advantages and political feasibility of issuing Eurobonds. Perceptions of fiscal transfers from 'northern' to 'southern' European countries, or lack of democratic support for fiscal federalism in Europe apparently hamper this solution in current circumstances. This kind of scepticism was not unlike the period we study. In 1833, the French government had trouble passing the Greek loan through the French Chambers. In 1855, it was the time of the House of Commons to raise serious objections to the Turkish loan on the grounds of the poor Ottoman credit and the unfortunate experience of the previous Greek guaranteed loan, which had been in default since 1836. After lengthy discussions, the guaranty for the Turkish loan was passed by a majority of only three, although it was raised to finance the Ottoman participation in the Crimean war on the side of Britain and France! These two cases show how political opposition to debt mutualisation was common before 1914. Strikingly, the arguments levelled against the issue of guaranteed bonds resonate very closely with the contemporary debate. Here we group them in four headings - convexity of yields, debt dilution and moral hazard, both on the side of debtors and creditors.

A first caveat raised against Eurobonds is the possibility of so-called convex yields, where the funding cost via Eurobonds can be higher than the aggregated sum of funding costs of Eurozone countries. Standard \& Poor's warned that the rating of an Eurobond may not be above, or even at the level of the average ratings of the participating nations, but in fact below, and possibly as lower as the lowest individual rating of the participating nations (EPDA 2008). This is, in practice, a statement about the convexity of risk premia, which may rise more than proportionally with the underlying risk factors. The worries about convex scenarios were already present in the nineteenthcentury debates. The Economist used precisely this argument in condemning the guaranty of the 1885 Egyptian loan: "It would be easy to show that the proposed international guaranty is unfair to us, because, if left to ourselves, we could raise the money at a lower rate than when our credit is 
impaired by being mingled with that of a country like Russia." ${ }^{4}$ Having said that, a first conclusion to take from the historical data is the absence of convex scenarios. Table 1 shows that guaranteed bonds were issued with an effective interest close to the average cost of funding of the guarantors; while in two cases the rate was below the average (Egypt in 1885 and Greece in 1898). The only possible support for this caveat is the first Greek loan of 1833 . The effective yield of this loan was 126 basis points above the average yields of the three guarantors. However, there are two alternative candidates to explain this. First is the fact that the loan only had a several guaranty. Second, the LSE refused to list the new loan pending the settlement of other Greek loans in default since 1826. As shown by Flandreau (2013) this failure to list involved a significant liquidity penalty, on the order of 150 to 200 basis points. ${ }^{5}$

A second line of criticism against Eurobonds highlights the risk of debt dilution. The dilution of existing bonds is an expected consequence of the seniority of Eurobonds. Several studies warn that a Modigliani-Miller effect may apply affecting the ability of nations' to roll over their stocks of 'red debt.' If a tranche of 'blue' bonds is introduced with seniority and enhanced guaranties, the remaining debt stock will have to bear the brunt of greater illiquidity and risk premia (Kopf 2011, Brunnermeier et al. 2011, Claessens et al. 2012). Despite the theoretical attention that this subject has attracted in the sovereign debt literature, Claessens et al. (2012) consider, in their review paper on the Eurobonds debate, that there is a dearth of analytical and empirical analysis of these effects. In the next sections we introduce a conceptual framework and bring out some historical evidence to test explicitly for dilution, which was also a repeated source of complaints from $19^{\text {th }}$ century bondholders. ${ }^{6}$

\footnotetext{
${ }^{4}$ Issue of 21 March 1885, p. 344.

${ }^{5}$ In a related paper, Collet (2013) studies the financial counterpart of Italian unification in 1861. She finds that the initial yield post-unification was actually above the maximum of the pre-unification yields of former Italian states, which would imply a 'super-convex' scenario. Consequently, this unification premium probably overstates the convexity of yields from pooling debts of independent sovereigns.

${ }^{6}$ See, for instance, Levandis (1944) on the conflict with Greek bondholders after the issue of the 1833 guaranteed bond, or the criticisms to the seniority of the Chinese loan of 1895 in the Economist 13.07.1895, p.
} 
Thirdly, moral hazard concerns loom large among the criticisms of Eurobonds (Issing 2009, Gros 2011 and Favero and Missale 2011, Kopf 2011). To address this issue, some of the Eurobonds proposals include federal control over countries' budgets, a step partly taken already with the enactment of the European Fiscal Compact in 2013. Others prefer adjusting the yields paid by participating countries (relative to the effective cost of funding of the Euro debt agency), so as to incentivise fiscal consolidation and prevent the build-up of unsustainable debts (Bonstra 2010, Dübel 2011, Muellbauer 2013, European Commission 2011). Similar to other caveats, moral hazard was equally a concern before 1914 and was frequently mentioned in connection with the example of the first Greek guaranteed bond of 1833. This loan, despite its formal seniority, quickly went on default in 1836 , and ultimately had to be paid by the guarantors. Unsurprisingly, the following four loans involved some form of conditionality. However, conditionality and guaranteed loans do not map one-to-one. First, the degree of conditionality varied from none or very weak interference to foreign control. For instance, the guaranty for the 1855 Ottoman Loan merely required that the proceedings of the loan were entirely used for war purposes. The 1898 Greek loan is the strongest case of conditionality, since it was floated after Greece accepted the establishment of an international financial control over some government revenues for the service of the external debt (Tuncer 2015). In the case of the 1885 Egyptian loan the order of events was reversed, because Britain and France already held the control of Egyptian finances since 1876. As discussed in the following sections, this control was not taken at face value by the markets during the early years, so unlike colonial bonds the value of the external guaranty was still priced by the markets.

Although not a commonly referred theme in the current Eurobonds debate, the history of guaranteed loans also reveals that creditors' moral hazard can be as much of a concern as debtors'. The extensive rivalry between European powers sometimes worked to the benefit of the assisted countries. In 1895, following the defeat in the war with Japan, China needed funds to pay the war

907. On the contemporary literature see Detragiache (1994), Bolton and Jeanne (2009) and Hatchondo, Martinez and Padilla (2012). 
indemnity. The Chinese government initially approached the British to organise the financial arrangements, but met with strong resistance from Russia, which was ultimately successful in floating a guaranteed loan through a joint Franco-Russian consortium. ${ }^{7}$ The conflict between guarantors was more serious in the case of the Greek loan of 1833, namely because the guarantors went to war with each other in 1853 ! The fact that this loan was issued under a several guaranty was also a source of trouble. As each guarantor was only responsible for a third of the loan, they repeatedly supported the Greek government in selectively defaulting against their opponents or used their share in the 1833 loan to court political favour in Greece (Levandis 1944, Kofas 1981). Unsurprisingly, this did not help with the governance of Greek debt. Not only did Greece remain in default on its non-guaranteed bonds until 1879 , but it also ended up paying back very little of the 1833 loan itself. ${ }^{8}$

Another source for creditors' moral hazard could be the non-overlapping geography of financial guaranties and foreign control. In general, in cases of international financial control, the countries with a representation in the control organization were not necessarily the same who were involved in the guaranteed loans. This lack of overlap could lead to confrontation between creditors with different incentives. The second Greek loan of 1898 is a good case in point. Germany, a country with little financial interest in Greece, was nevertheless very involved in the negotiation of the Greek debt workout. Despite not being one of the guarantors of the 1898 loan, it acquired a seat in the International Financial Commission, which controlled Greek finances from then on. The financial guaranty of the other Powers allowed Greece to pay the war indemnity to Turkey, a country in which Germany held a large investment position. Consequently, Germany lobbied for a harsher deal for Greece than what the other powers were prepared to settle for (Levandis 1944, Wynne 1951). Following the Egyptian guaranteed loan of 1885 a similar conflict of interests emerged regarding the representation in the Egyptian Caisse de la Dette Publique. The Caisse, created right after the 1876

\footnotetext{
${ }^{7}$ FO (1895) Miscellaneous Papers, Vol. 48 and MacMurray (1921).

${ }^{8}$ In 1864 Greece reached an agreement with the powers to retire the 1833 loan. According to Wynne (1951), by then Britain had paid $£ 1.2$ million on charges of the loan and had only received $£ 100,000$ from Greece.
} 
default, was managed by British, French, Austro-Hungarian and Italian commissioners. The 1885 loan, however, was guaranteed by six powers, two of which, Germany and Russia, did not have a seat in the Caisse. The arrangement allowed a relative flexibility to the Egyptian government to use the reserve funds of the Caisse to meet its expenditure. Although the share of Russian and German bondholders in Egyptian debt was very small, the two countries raised concerns about the possibility of the Egyptian government diverting revenues from the Caisse. Despite the discontent of the other members, Germany and Russia eventually gained a representation in the Caisse in 1885 . From this year on, the Caisse accumulated significant reserves by limiting the Egyptian government's ability to spend them (Colvin 1906, Wynne 1951, Tuncer, 2015).

On the eve of the settlement of the Ottoman default, Britain and France, the guarantors of 1855 loan, jointly held almost 90 per cent of the Ottoman debt; hence they were keen to introduce a strong international control over Ottoman finances with their joint representation. The Ottoman government, however, wary of what was going on Egypt at the time, was determined not to hand too much sovereignty to its foreign creditors. As a result, the Porte turned to Germany that held no more than 8 percent of the Ottoman debt, and hired German advisors to help it with the negotiations. During the talks, while Britain and France were pushing for a harsher deal, the German bondholders' representative was keener on compromise. Thanks to German support, the Ottoman government secured an advantageous deal involving a 50 per cent write-down of its outstanding debt and more than 80 per cent of its interest arrears. Furthermore, the international financial control was shared between the representatives of all European creditor nations, large and small: Britain, France, Germany, the Netherlands, Italy and Austria-Hungary (Pamuk 1978, Clay 2000, Tuncer 2015, Yackley 2013).

Here too one is drawn to see parallels with the non-overlapping architecture of the EU and the Eurozone for the evolution of the European debt crisis. Whilst financial stability in the Eurozone has 
positive externalities for the rest of Europe and the World, financial responsibility has mainly remained within the Eurozone member countries. ${ }^{9}$

\section{Debt dilution, fiscal discipline and spreads}

In this section we lay down a simple framework to think about the consequences of issuing guaranteed bonds. Let $s_{g}$ be the fraction of total debt guaranteed ex-post, which is a multiple of the original $B^{\prime}=(1+\delta) B$, where $\delta$ can be positive or negative. If multilateral debt is simply added to the debt stock then $\delta>0$. However, if there is a simultaneous debt write-down, it is possible that $\delta<0$. As the new guaranteed bonds are issued with seniority and the explicit guaranty, their yield must be lower than that paid by the country before the announcement of the financial assistance: $r_{g}<r$. Without loss of generality, assume a linear relation between bond yields and debt stocks $r=\alpha B .^{10}$ The shadow yield for the new debt stock would then be $r^{\prime}=\alpha(1+\delta) B=(1+\delta) r$. The actual yield on the two classes of bonds depends on their shares, according to the ex-post identity:

$$
(1+\delta) r=s_{g} r_{g}+\left(1-s_{g}\right) r_{o}
$$

where $r_{o}$ is the ex-post yield on the legacy debt. This identity expresses the Modigliani-Miller effect, according to which the composition of the new debt stock (the right-hand side) should not impact the average cost of funding, once changes in the total stock are taken into consideration (left-hand side). We can now solve (1) for the ex-post spread between the guaranteed and the non-guaranteed bonds:

$$
r_{o}-r_{g}=r-r_{g}+\frac{s_{g}}{1-s_{g}}\left(r-r_{g}\right)+\frac{\delta}{1-s_{g}}
$$

\footnotetext{
${ }^{9}$ With the exception of the bilateral British and Dutch loans to Ireland in 2010.

${ }^{10}$ It is straightforward to show that the decomposition of the results in this section extends to other functional forms.
} 
This new expression decomposes into three parts. The first term in the right-hand side is simply the ex-ante spread. The second term is a pure debt dilution effect: a large $s_{g}$ will put pressure on the yields of legacy debt and, ceteris paribus, also on the cost of funding. Finally, the third term represents the increase (decrease) in spreads due to an increase (decrease) in the total debt stock. This means that a debt write-down could decrease ex-post yields. Consequently, 'blue' bonds need not destabilise the sovereign debt market if the share of 'blue bonds' is large enough to improve fiscal sustainability ratios, but small enough to allow countries to maintain market access at affordable interest rates (Gros 2010).

These are, of course, not the only determinants of the bond yields, but the remaining factors are likely to cancel out in the expression (2). A way of seeing this is to decompose the yields of the several classes of bonds from first principles:

$$
\begin{gathered}
r_{p}=r_{f}+\tilde{r}_{l i q}+\tilde{r}_{\text {risk }} \\
r_{g}=r_{p}+\left(r_{l i q}-\tilde{r}_{l i q}\right) \\
r_{o}=r_{f}+r_{\text {risk }}+r_{l i q}+r_{s}+r_{\delta}
\end{gathered}
$$

where $r_{p}$ is the cost of funding of the guarantors, which is above the risk-free rate $r_{f}$, by their aggregate risk and liquidity premia $\left(\tilde{r}_{\text {risk }}\right.$ and $\left.\tilde{r}_{\text {liq }}\right)$. These are not necessarily the average of the individual premia, because of convex scenarios or because markets may discount bonds issued with several but not joint guaranties. In the second line, the yield on the guaranteed bonds is not simply given by $r_{p}$ because the guarantors only mutualise a fraction of their own debt stocks, so the gain in liquidity from issuing guaranteed bonds was likely to be insignificant. Finally, the ex-post yield on previous bonds depends on the same country-specific liquidity and risk premia, and the two terms $r_{\delta}$ and $r_{s}$, representing the dilution and debt stock effects from expression (2). ${ }^{11}$ Subtracting the two last expressions we get the ex-post spread:

$$
r_{o}-r_{g}=\left(r_{\text {risk }}-\tilde{r}_{\text {risk }}\right)+r_{s}+r_{\delta}=r-r_{g}+r_{s}+r_{\delta}
$$

\footnotetext{
${ }^{11}$ Note that we separate $r_{\text {risk }}$ from the two last terms since it represents the risk assessment of the country prior to the changes in composition $\left(r_{s}\right)$ and size $\left(r_{\delta}\right)$ of the country's debt stock.
} 
which is consistent with (2). In the next section, we quantify dilution effects from short-run price movements of legacy bonds. But another implication from (3) is that seniority and guaranties should affect the long-term relationship between guaranteed and non-guaranteed bonds. In particular, whilst $r_{g}$ is priced on the risk of the guarantors, $r_{o}$ still reflects the country-specific credit risk. Hence, $r_{g}$ should be affected by $\tilde{r}_{\text {risk }}$ and less so by $r_{\text {risk }}$. We will test these hypotheses from the time series behaviour of the various bond yields.

\section{Empirical analysis}

\subsection{Data}

In our empirical analysis we use 17 bond series, comprising 5 guaranteed bonds, 7 non-guaranteed bonds, and 5 bonds from the main guarantors (the UK, France, and Russia). Our first empirical exercise focuses on the short-term dynamics of adjustment to the issue of guaranteed bonds. For that purpose we use daily prices of the bonds (Table 2). The second exercise studies the long-term relation between guaranteed and non-guaranteed bonds. Because of the length of the periods considered, we use monthly data, as described in Table 3.

\section{Tables 2 and 3 here}

The figures in Table 2 are expressed in simple yields (coupon/price), which is not an accurate measure of the cost of borrowing as it ignores the bond maturity and the impact of any callable options included in many bonds. Nevertheless, in looking for the short-run impact of guaranteed bonds, we are really interested in the reaction of bond prices, which are immune to these biases. This option is less defensible for the monthly dataset, which covers a long period approaching the maturity of some of the bonds used in the analysis. Consequently, we considered two alternative yield measures: yield-to-maturity (YTM) and yield-to-call (YTC), as described in the Appendix. We 
decided to use the YTM, as the YTC underestimates the true spread between non-guaranteed and guaranteed bonds $r_{\mathrm{o}}-r_{\mathrm{g}}$, while simple yields overestimate it.

\subsection{Short-term: dilution}

In this section we identify the reaction of pre-existing or 'red' bonds to the introduction of the five guaranteed loans, particularly the debt dilution effect. To formally identify breakpoints in the price series we resort to Bai and Perron's $(1998,2003)$ methodology. Table 4 lists the break dates together with plausible historical events that could explain them. As a source of public information we use the British and French daily press, especially the issues of The Times.

\section{Table 4 here}

We need to interpret the identification of news from the press with care for two reasons. The first is that we cannot observe insider information, which might be reflected in the bond prices before it made it into the pages of the dailies. Nevertheless, the lag between these two events must not have been too long to invalidate the exercise. Moreover, Bai and Perron's method provides confidence intervals for the breakpoint estimates, which are represented by the shaded areas in Figures $1-5 .{ }^{12}$

\section{Figures 1-5 here}

In these figures the solid vertical lines mark the point estimates of structural breaks, whereas the two vertical thick lines date the first day when the press reported the intention to issue a guaranteed bond (dashed) and the date when the loan was effectively floated in the market (dashdotted line).

The second caveat of this exercise has to do with the usual errors in statistical inference. On the one hand, there is a type I error-as we only concentrate on the dates identified by the statistical

\footnotetext{
${ }^{12}$ Some of these areas overlap, but that is essentially because we used more than one comparing bond for some countries.
} 
procedure, we may be ignoring other relevant news published on dates which were not picked up by our breakpoint dating method. The sudden jump in Egyptian yields shortly after the announcement of the guaranteed loan exemplifies this (Figure 3). Table 4 lists other four cases in bold. Then, there is the question about the power of the breakpoint test, which may overidentify breaks. ${ }^{13}$ Nevertheless, the majority of the identified breaks have support in contemporary events, and the reaction of the bond prices also accords with the nature of the information published by the press.

Only on two occasions did yields rise markedly on legacy bonds: the early Greek case and the Egyptian convention of 1885. In the first case, the yields of the independence loans rose by about 29\% immediately after the public announcement of the guaranteed loan in early August 1832. However, this initial reaction was quickly reversed, on the force of the encouraging noises coming from the several governments involved (Levandis 1944, Kofas 1981). The unusually long gap between the announcement and the actual issue of the guaranteed bond ( 12 months) allowed bondholders plenty of time to inform themselves of the details of the financial operation and, in particular, of its consequences for their own claims. Even though the yields on the independence bonds fell all the way until the issue of the new loan in July 1833, the bondholders' expectations were shattered on 10 October when the Greek regency informed that it did not recognise their claims. On that date, the yield on Greek bonds almost exactly matches the prediction of equation (2). The formula predicts a yield of $21.9 \%$ for the independence bonds against the $22.2 \%$ effectively priced on the market. ${ }^{14}$ Despite this dramatic reversal, the prices of Greek bonds recovered quickly and stabilised at a level similar to that prior to the announcement of the financial guaranty.

In the Egyptian case, the yields of the legacy bonds rose by $15 \%$ on average between the announcement that all powers had accepted to guarantee the new Egyptian bond (on 19 March

\footnotetext{
${ }^{13}$ There were four breaks for which we could not find any significant piece of published news (see Table 4).

${ }^{14}$ The new guaranteed loan added one third to the total debt outstanding $(\delta=0.33)$, the fraction of 'blue' bonds was therefore a quarter $\left(s_{g}=0.25\right)$, the average yield on the guaranteed bond in September 1833 had been $r_{g}=4.8 \%$ and, finally, the yields on the independence loan had averaged $r=13.2 \%$ over the same period. Applying expression (2) results in an ex-post prediction of $r_{o}=21.9 \%$.
} 
1885 ) and the end of April. This rise too was entirely reversed over the rest of the year. However, the identification of the start of the 'Egyptian event' is less clear than in the early Greek case because the British government had been pressing ahead with the idea of a new loan under international guaranty since at least April 1884. It is therefore possible that markets priced dilution not on March-April 1885, but on April-June of the year before, when yields also increased markedly.

By contrast, yields reacted favourably on the three other cases. This is especially clear in the later Greek episode. The introduction of external financial control simultaneously with the Greek 1898 loan is certainly not immaterial to this result and the subsequent reduction in Greek yields until the end of 1899. Moreover, and unlike the 1833 operation, the guaranteeing powers imposed a $61 \%$ haircut, thereby calibrating the issue of the 'blue bonds' not to burden Greece with a new debt stock it could not service. ${ }^{15}$

As a final test of the dilution hypothesis, we conducted an event study following standard methodologies (Campbell, Lo and MacKinlay 1997). The results of the event studies are not entirely consistent across the different test statistics. ${ }^{16}$ Nevertheless, the preponderance of evidence is that the announcement of guaranteed bonds had no significant impact on the returns of legacy bonds or, in fact, had a positive effect. This is consistent with the graphical impression from Figures 2-5.

A conservative conclusion from this section must therefore be that, though possibly present, there is no strong evidence of dilution effects in the cases studied in this paper. The first Greek bond of 1833 comes closer to a case of dilution, but even here only for a short while, as illustrated by the fast reversal of yields on the 1825 independence bonds after the initial announcement shock (Figure 1). Furthermore, in all cases, the introduction of an international guaranty was a response to desperate financial positions brought about by extraordinary political circumstances. Many advocates of Eurobonds today explicitly separate them from the resolution programmes for

\footnotetext{
${ }^{15}$ Turkish yields in 1855 are harder to interpret as they also reacted to the news about the Crimean war. In that sense, the issue of the new loan could count as good news for the bondholders as it signified the commitment of Britain and France to stand by their ally in the war against Russia.

${ }^{16}$ The results are described in the Appendix.
} 
countries under financial duress, which would not be eligible to issue Eurobonds. Consequently, the historical evidence suggests that debt mutualisation in Europe could probably avoid signification dilution effects, especially if excluding programme countries.

\subsection{Long term pricing of guaranties}

As we described in section 3 , the different underlying risk structure of guaranteed and nonguaranteed bonds must have affected their long-term relationship. In this section we test the assertion that guaranteed bonds were priced on the credit risk of the guarantors $\left(\tilde{r}_{\text {risk }}\right)$, rather than on the country-own risk $r_{\text {risk }}$. Table 5 and Figure 6 represent the long-term evolution of the spread between non-guaranteed and guaranteed bonds $\left(r_{0}-r_{\mathrm{g}}\right)$ for four out of the five cases under study. ${ }^{17}$

\section{Table 5 and Figure 6 here}

With the exception of China, guaranteed bonds started with high discounts, close to 300 basis points against pre-existing bonds. ${ }^{18}$ With time the discount converged to lower values, especially in the cases of Egypt and Greece. Interestingly, despite being issued already under foreign control, the Egyptian guaranteed loan started off with a particularly high discount, which only came down to 100 basis points after five years. Similarly, the inauguration of the Ottoman Public Debt Administration, after the Turkish default in 1875-1881, had a moderate impact on the spread between guaranteed and non-guaranteed bonds, which fell by little more than 80 basis points between the pre-default and the post-workout periods. A more significant compression in the spread occurred after 1888 , probably because of a further handover of fiscal sovereignty to the Ottoman Public Debt

\footnotetext{
${ }^{17}$ We left out the initial Greek bond out as the 5\% independence bonds were in default until 1879 and, consequently, are not a good measure of the Greek marginal cost of funding. For the same reason, we excluded the period when Turkey was on default (from October 1875 to December 1881).

${ }^{18}$ In the case of Turkey the values in Figure 6 do not go back to the issue of the guaranteed bond, in 1855, because the IMM only started publication in 1869. However, the initial spread hovered around 300 basis points (Figure 2). The data ends in June 1894 not to have a disproportionally long sample relative to the other three cases. The results do not change materially, though, when we extend the Turkish time series to December 1907.
} 
Administration (Tuncer 2015). The spread opened up again after 1890 in a seeming reflection of the Barings crisis.

Some of the spread series exhibit systematic changes, such as the drop in the Chinese discount after 1903, entirely driven by an increase in the yields of the guaranteed bonds. This was in turn caused by the widening of spreads on the bonds of the guaranteeing power, Russia, with the start of the Russo-Japanese war in 1904. The Greek series also reacted to the lower quality of the Russian guaranty, and show the same short-run adjustment to the introduction of international financial control in 1898. The longer-term data, however, reveal that the initial drop in the spreads of nonguaranteed debt was not only quickly reversed by mid-1899 but persisted throughout the early 1900s. The two-step jumps in the discount in 1906 and 1907 can be associated with adverse fiscal and political news. ${ }^{19}$

In analysing the long-term relation between guaranteed and non-guaranteed bonds, we follow two approaches. First, we use factor analysis to identify the common factors to each country's bonds and its guarantors. We then extend the analysis by using panel VARs (PVAR). Table 6 and Figure 7 summarise the results from factor analysis.

\section{Table 6 and Figure 7 here}

Table 6 shows that uniqueness is low, which implies that the individual bond spreads are adequately explained by the factors. The factor loadings of the first factor on non-guaranteed bonds are usually smaller than those on the guaranteed bonds or the bonds of the guaranteeing powers. The converse is true of the second factor, when retained, so we interpret the first factor as capturing world or exogenous cost of credit, and the second the domestic risk component.

\footnotetext{
${ }^{19}$ For instance, in June 1907 the Economist referred to a report by the International Financial Commission on the unreliable Greek budget figures, which despite showing surpluses since 1898, had actually been on deficit in every year until 1905 (issue of 22.6.1907, p. 1063).
} 
This interpretation is confirmed when we plot the factor loadings for the two countries for which we retained two factors. Figure 7 clearly shows the association between the guaranteed bonds and the bonds of the guaranteeing powers - Britain and France (less so of Russia). Instead, the pricing of domestic bonds is plainly driven by the second factor. The exception is China, where the Cassel loan has a larger factor loading than the guaranteed Franco-Russian loan of 1895 . This is probably due to the peculiar political situation of the Chinese Empire. Although not guaranteed, the Cassel loan was interpreted as the German-British reaction to the Franco-Russian guaranteed bond. Consequently, the two Chinese bonds reacted in tandem with the credit of the two competing groups of powers, as a financial expression of the foreign spheres of influence being delimited the time in China.

Panel VARs extend the VAR approach to allow for unobserved individual country heterogeneity. We specify a first-order VAR model:

$$
Y_{i t}=\Gamma_{0}+\Gamma(L) Y_{i t}+v_{i}+\varepsilon_{i t}
$$

where $Y_{i t}$ is a vector of endogenous variables (bonds yields), $\Gamma_{0}$ is a vector of constants, $\Gamma(L)$ is a matrix polynomial in the lag operator, $v_{i}$ is a matrix of country-specific fixed effects, and $\varepsilon_{i t}$ is a vector or error terms (with zero mean and country-specific variance). The correlation between the fixed effects and the regressors due to lags of the dependent variables implies that the commonly used mean-differencing procedure creates biased coefficients (Holtz-Eaking et al. 1988). A two-step procedure solves this. First, we use the 'Helmert procedure' of forward mean-differencing that only removes the mean of all future observations of each country-year (Arellano and Bover 1995) and second, we estimate the system by GMM (Arellano and Bond 1991). ${ }^{20}$

Since the variance-covariance matrix of the error terms may not be diagonal, we orthogonalise the residuals through a Choleski decomposition. We ordered the bonds of guaranteeing powers first, starting with Britain and following with France and Russia. Because of the nature of international

\footnotetext{
${ }^{20}$ We tested all transformed variables for unit roots by using a Fisher-type test that allows for large T-small $\mathrm{N}$ panels (Choi 2001) and could reject them for all panels.
} 
guaranties, we ordered the guaranteed bonds second, and the non-guaranteed domestic bonds last. ${ }^{21}$ Finally, given the relatively low frequency of the data, we only ran the models with one monthly lag. Tables 7-10 list the estimation results expressed as the variance decomposition of each bond up to 10 months after a shock.

\section{Tables 7-10 here}

Despite the low data frequency, the results are consistent with the ordering of the variables in the PVARs in the sense that the variables ordered first do not respond to shocks to variables ordered later. For instance, the variance of British bonds (arguably the world benchmark) is hardly explained by any other yields in the systems. French yields only react to British yields, and so on. The variance of guaranteed bonds is explained in large share by the yields of guarantors, but not by other domestic bonds. The latter, on the other hand, react to foreign benchmark yields (mostly British), but not to the yields of guaranteed bonds, which underscores the separation of the two classes of bonds over the long-run. The impulse response functions (unreported) specify further these results by showing that a shock to British yields has positive and long-lasting effects on all other bonds. ${ }^{22}$ However, the size of the effects is smaller than one, meaning that increases in the benchmark yield narrowed spreads, as has been found elsewhere (Eichengreen and Mody 2000). The size of the reactions of the yields of guaranteed bonds was also consistent with the ordering of the guaranteeing powers, being larger in the IRF to shocks to British yields than to French and Russian.

The evidence from factor analysis and PVARs is consistent in revealing the distinct way in which markets priced guaranteed and non-guaranteed bonds. The former reacted to the cost of credit of the guarantors, whereas the latter did not (except for the British benchmark). Such evidence underscores once more that guaranteed bonds were interpreted as a form of debt mutualisation by the markets.

\footnotetext{
${ }^{21}$ We also experimented with different orderings within these three groups of bonds, where possible, but the results did not differ materially.

${ }^{22}$ Complete results are available from the authors on request.
} 


\section{Conclusions}

This paper contributes to the debate on debt mutualisation through the issue of Eurobonds as a solution to the fiscal crisis in the Eurozone by providing the first empirical analysis of the closest available historical parallels: the pre-1914 guaranteed bonds. We started by uncovering a nineteenth-century debate, which shares uncanny similarities with the current arguments pro and against Eurobonds. Despite domestic political opposition, the European powers got involved in these operations to achieve financial and political stability in sensitive areas of the world. As envisaged by today's proposals, these bonds were seen by the markets as instances of debt mutualisation. On the basis of this parallel, we then used market data for these bonds to reach three policy-relevant conclusions.

First, that the fears about short-run dilution and destabilisation of the debt market of weaker nations may be overplayed. On the one hand, hardly anyone proposes the introduction of Eurobonds without concomitant moves towards greater fiscal discipline (or federalism). On the other, our historical case studies show that even for countries in desperate financial condition, debt dilution and rationing of 'red bonds' were either absent or temporary. In some cases this was achieved through international financial control (a nineteenth-century version of conditionality), though not all countries studied experienced this infringement to their sovereignty. In other cases, write-downs of existing debt were also instrumental in stabilizing the sovereign debt market after the issue of guaranteed loans.

Second, the combination of guarantors with different credit standing did not penalise the yields of the guaranteed bonds significantly. Apart from the first Greek bond of 1833, which was floated with a yield above the average of the guarantors' cost of funding, all other guaranteed bonds were floated below this average and increasingly closer to British yields, whenever the UK was involved. Hence, the worries about 'convex scenarios' for Eurobonds may also be exaggerated. In other words, 
the scale of fiscal transfers from strong countries, like Germany, to weaker nations may be smaller than feared by many.

Third, markets persistently priced mutualised debt separately from the countries' own bonds. Although the spreads between guaranteed bonds and the marginal cost of funding of borrowers varied over time they seldom fell below 100 basis points, even in the stronger cases of international financial control (Egypt and Greece). Given the relatively small size of the guaranteed issues, with respect to the debt stock of the guarantors, this is certainly due to the markets pricing the guaranteed bonds on the basis of the credit risk of the guarantors. This was not always a good thing, as exemplified by the transmission of the credit risks from the Russo-Japanese war to the Chinese and Greek bonds guaranteed by Russia. The reaction of the spreads of the EFSF bonds to the downgrade of eight of the guaranteeing sovereigns in late 2011 are a contemporary illustration of this effect.

Nevertheless, the overall tendency for the spread of domestic debt was to decrease with respect to guaranteed bonds, which intimates an improvement in the financial condition of the countries after the mutualisation of part of their debt. However, the behaviour of Eurozone spreads after 1999 should alert us to the questionable ability of markets to price sovereign risk. Ex post, debtor countries could have used the better credit of their guarantors as a way of borrowing beyond their limits, as feared by many contemporary critics of Eurobonds. Wary of this issue, nineteenth-century guarantors started considering guaranties in the context of stronger forms of conditionality, namely international financial control. Even so, this study revealed that moral hazard could emerge both on the part of the assisted debtors and of their guarantors. The latter occurred when the nature of the guaranty (several only) did not lead to co-operation among guarantors. Or then in situations where international financial control did not match with the provision of guaranties, a case not unlike the current non-overlapping architecture of the EU and the Eurozone. 
Table 1: Summary information on guaranteed bonds, 1832-1898

\begin{tabular}{|c|c|c|c|c|c|c|c|c|c|c|}
\hline Loans & Cause & Guarantors & $\begin{array}{l}\text { Face } \\
\text { value } \\
(E \mathrm{~m})\end{array}$ & $\begin{array}{l}\text { Previous } \\
\text { debt }(£ \mathrm{Em})\end{array}$ & $\begin{array}{c}\text { Nominal } \\
\text { Interest } \\
(\%)\end{array}$ & $\begin{array}{c}\text { Yield at } \\
\text { issue } \\
(\%)\end{array}$ & $\begin{array}{l}\text { Cost of } \\
\text { funding } \\
(\%)\end{array}$ & Secured by & Conditions & Redemption \\
\hline $\begin{array}{l}1855 \\
\text { Turkish } \\
\text { Loan }\end{array}$ & $\begin{array}{l}\text { Crimean } \\
\text { war }\end{array}$ & Britain, France & 5.0 & 2.9 & 4 & $3.90 \%$ & $3.9 \%$ & $\begin{array}{l}\text { Egyptian tribute, } \\
\text { customs of Izmir } \\
\text { and Syria }\end{array}$ & $\begin{array}{l}\text { British-French commission to } \\
\text { supervise the expenditure of funds } \\
\text { for war purposes }\end{array}$ & 1943 \\
\hline $\begin{array}{l}1885 \\
\text { Egyptian } \\
\text { Loan }\end{array}$ & $\begin{array}{l}\text { British } \\
\text { military } \\
\text { campaign }\end{array}$ & $\begin{array}{l}\text { Britain, France, } \\
\text { Russia, } \\
\text { Germany, } \\
\text { Austria- } \\
\text { Hungary, Italy }\end{array}$ & 9.424 & 99.0 & 3 & $3.14 \%$ & $4.2 \%$ & Property tax & $\begin{array}{l}5 \text { per cent discount on coupons of } \\
1885 \text { and } 1886 \text {. International } \\
\text { financial control by Britain, } \\
\text { France, Italy and Austria-Hungary, } \\
\text { later extended to include Germany } \\
\text { and Russia. }\end{array}$ & 1926 \\
\hline $\begin{array}{l}1895 \\
\text { Chinese } \\
\text { Loan }\end{array}$ & $\begin{array}{l}\text { Sino- } \\
\text { Japanese } \\
\text { war }\end{array}$ & Russia, France & 16.0 & 3.3 & 4 & $4.03 \%$ & $4.0 \%$ & Maritime Customs & Seniority clause & 1931 \\
\hline $\begin{array}{l}1898 \\
\text { Greek } \\
\text { Loan }\end{array}$ & $\begin{array}{l}\text { Greek- } \\
\text { Turkish } \\
\text { war }\end{array}$ & $\begin{array}{l}\text { Britain, France, } \\
\text { Russia }\end{array}$ & 6.0327 & 32.0 & 2.5 & $2.50 \%$ & $2.9 \%$ & State monopolies & $\begin{array}{l}\text { International financial control } \\
\text { shared by Austria- Hungary, } \\
\text { France, Germany, Great Britain, } \\
\text { Italy and Russia }\end{array}$ & 1950 \\
\hline
\end{tabular}

Sources: Wynne (1951) and CFB (1930) cover most of the information. On Chinese loans see Denby (1916) and Feng-Hua (1919).

Note: the average cost of funding is established from the secondary yields of the following loans (when applicable): the $3 \%$ British consols, the $3 \%$ French Rentes, the $4 \%$

Russian Nicholas Railway, the 4\% Prussian consolidated, the 4\% Austrian Gold Rentes and the 5\% Italian Rendita (4.6\%). 
Table 2: Bonds used in the short-run analysis

\begin{tabular}{|c|c|c|c|c|c|c|c|}
\hline \multirow[t]{2}{*}{ Bond } & \multicolumn{2}{|c|}{ Dates } & \multicolumn{5}{|c|}{ Simple yields } \\
\hline & Start & End & $\mathbf{N}$ & Mean & St. dev. & Max & Min \\
\hline 5\% Greek 1833 & $4 / 11 / 1833$ & $31 / 12 / 1834$ & 346 & 4.43 & 0.05 & 4.56 & 4.24 \\
\hline 5\% Greek 1825 & $17 / 1 / 1832$ & 18/11/1834 & 218 & 16.99 & 2.82 & 25.64 & 11.83 \\
\hline 4\% Turkey 1855 & 20/08/1855 & $19 / 12 / 1856$ & 337 & 3.97 & 0.11 & 4.19 & 3.74 \\
\hline 6\% Turkey 1854 & $23 / 08 / 1854$ & $19 / 12 / 1856$ & 593 & 6.68 & 0.77 & 8.23 & 5.58 \\
\hline 3\% Egypt 1885 & $28 / 08 / 1885$ & $31 / 12 / 1885$ & 57 & 3.09 & 0.02 & 3.12 & 3.04 \\
\hline 4\% Egypt unified 1880 & $2 / 1 / 1884$ & $31 / 12 / 1885$ & 490 & 6.24 & 0.28 & 7.05 & 5.79 \\
\hline 5\% Egypt State domain 1878 & $2 / 1 / 1884$ & $30 / 12 / 1885$ & 369 & 5.83 & 0.20 & 6.57 & 5.42 \\
\hline 4\% Chinese 1895 & 20/07/1895 & $31 / 12 / 1895$ & 131 & 3.96 & 0.02 & 4.01 & 3.92 \\
\hline $6 \%$ Chinese of 1895 (Cassel) & $4 / 5 / 1895$ & $31 / 12 / 1895$ & 139 & 5.69 & 0.07 & 5.90 & 5.53 \\
\hline 2.5\% Greek 1898 & $8 / 11 / 1898$ & 25/09/1899 & 39 & 2.49 & 0.03 & 2.62 & 2.46 \\
\hline 5\% Greek 1881† & $3 / 1 / 1898$ & 25/09/1899 & 154 & 3.97 & 0.26 & 4.81 & 3.58 \\
\hline $5 \%$ Greek $1884 \dagger$ & 4/1/1898 & 25/09/1899 & 106 & 3.98 & 0.27 & 4.78 & 3.57 \\
\hline
\end{tabular}

Table 3: Bonds used in the long-run analysis

\begin{tabular}{|c|c|c|c|c|c|c|c|c|}
\hline \multirow{2}{*}{$\begin{array}{l}\text { Bond } \\
\text { Name }\end{array}$} & \multirow[b]{2}{*}{ Acronym } & \multicolumn{2}{|c|}{ Dates } & \multicolumn{5}{|c|}{ Yield-to-maturity (YTM) } \\
\hline & & Start & End & $\mathbf{N}$ & Mean & St. dev. & Max & Min \\
\hline 4\% Turkey 1855 & y1855 & $1 / 1869$ & $6 / 1894$ & 301 & 3.46 & 0.69 & 4.17 & 0.41 \\
\hline 6\% Turkey 1854 & y1854 & $1 / 1869$ & $6 / 1894$ & 303 & 7.80 & 3.92 & 29.43 & 2.48 \\
\hline 3\% Egypt 1885 & y1885 & $3 / 1886$ & $12 / 1907$ & 259 & 2.95 & 0.17 & 3.43 & 2.57 \\
\hline 4\% Egypt unified 1880 & yunif & $3 / 1886$ & $12 / 1907$ & 262 & 4.11 & 0.51 & 5.96 & 3.65 \\
\hline 5\% Egypt State domain 1878 & ystate & $3 / 1886$ & $12 / 1907$ & 262 & 4.63 & 0.38 & 5.66 & 4.19 \\
\hline 4\% Chinese 1895 & y1895 & $8 / 1895$ & $12 / 1907$ & 149 & 4.10 & 0.25 & 4.81 & 3.77 \\
\hline $6 \%$ Chinese of 1895 (Cassel) & ycassel & $8 / 1895$ & $12 / 1907$ & 147 & 5.71 & 0.21 & 6.48 & 5.31 \\
\hline 2.5\% Greek 1898 & y1898 & $10 / 1898$ & $12 / 1907$ & 111 & 2.93 & 0.18 & 3.23 & 2.51 \\
\hline 5\% Greek 1881† & y1881 & $10 / 1898$ & $12 / 1907$ & 111 & 5.38 & 0.47 & 6.11 & 4.43 \\
\hline $5 \%$ Greek $1884 \dagger$ & y1884 & $10 / 1898$ & $12 / 1907$ & 111 & 5.19 & 0.45 & 5.85 & 4.26 \\
\hline $3 \%$ UK Consols & ygbr & $1 / 1869$ & $4 / 1888$ & 229 & 3.10 & 0.12 & 3.35 & 2.90 \\
\hline 2.75\%-2.5\% UK Consols & ygbr & $5 / 1888$ & $12 / 1907$ & 236 & 2.60 & 0.24 & 3.09 & 1.95 \\
\hline 4.5\% French bond of 1852 & yfra & $1 / 1869$ & $3 / 1871$ & 18 & 4.47 & 0.30 & 5.63 & 4.30 \\
\hline 3\% French Rentes & yfra & $4 / 1871$ & $12 / 1907$ & 438 & 3.63 & 0.74 & 5.85 & 2.78 \\
\hline 4\% Russian 1867 (Nicholas RR) & yrus & 9/1895 & $12 / 1907$ & 148 & 4.25 & 0.46 & 5.55 & 3.88 \\
\hline
\end{tabular}

tInterest reduced to $1.6 \%$ since 1898 and later increased till 2.2\%. Sources: the Paris Bulletin de la cote for the Chinese guaranteed bond and the Investor's Monthly Manual (IMM) for all other bonds. 
Table 4: Dates of structural breaks in bond yields

\begin{tabular}{|c|c|c|c|}
\hline Case & Date & 95\% C.I. & Interpretation (from press) \\
\hline \multirow[t]{8}{*}{ Greece 1833} & 09/03/1832 & 04/03-16/04 & \\
\hline & 06/08/1832 & 21/07-13/09 & Palmerston introduces the Greek convention bill in Parliament (inc guaranteed bond) \\
\hline & $26 / 12 / 1832$ & $26 / 12-27 / 01$ & Bavarian banker Eichthal arrives to Paris "for the purpose of pressing the business of the Greek loan" \\
\hline & $19 / 02 / 1833$ & $31 / 01 /-25 / 02$ & Rothschild (Paris) is rumoured to have taken the loan contract \\
\hline & $26 / 05 / 1833$ & $08 / 05-27 / 08$ & French Chamber ratifies French share of guaranty, after much opposition \\
\hline & $20 / 07 / 1833$ & & Floating of bond in London \\
\hline & 09/11/1833 & 26/09-13/10 & Greek regency refuses to recognize claims of bondholders of the two independence loans \\
\hline & 02/04/1834 & $31 / 03-20 / 06$ & Greek Prime Minister Trikoupis meets with William IV, king of United Kingdom \\
\hline \multirow[t]{9}{*}{ Turkey 1855} & 06/11/1854 & $04 / 11-25 / 11$ & News of assaults and naval bombardment of Sebastopol by allied armies \\
\hline & 19/12/1854 & $07-12-27 / 12$ & Final instalment (15\%) of Turkish script paid \\
\hline & $27 / 05 / 1855$ & 26/05-01/09 & Large purchases from Paris on rumours that Turkish government would issue the remaining $f 2 \mathrm{~m}$ of the 1854 loan soon \\
\hline & $9 / 07 / 1855$ & & Announcement of the Turkish convention (which had been signed on 27jun1855) \\
\hline & $15 / 07 / 1855$ & $10 / 07-23 / 07$ & Announcement that the guaranty of the Turkish loan would be joint \\
\hline & 20/08/1855 & & Floating of bond in London \\
\hline & 25/09/1855 & 26/08-02/09 & Announced the payment of dividends on the Turkish bonds \\
\hline & 23/01/1856 & 17/01-19/02 & Final instalment on the guaranteed loan due \\
\hline & $08 / 10 / 1856$ & $02 / 10-19 / 12$ & Rumours that a new Turkish loan was being contemplated \\
\hline \multirow[t]{6}{*}{ Egypt 1885} & $14 / 05 / 1884 \dagger$ & 03/05-17/05 & Announcement of the Conference of the Great powers to be held in London to discuss the revision of Law of Liquidation \\
\hline & 27/05/1884‡ & 20/05-03/06 & French proposal to extend the control over Egypt by involving other Great powers \\
\hline & $22 / 10 / 1884 \ddagger$ & $22 / 10-29 / 10$ & \\
\hline & $24 / 10 / 1884 \dagger$ & $14 / 09-14 / 11$ & Announcement of the report of British representative Edgar Vincent on the finances of Egypt \\
\hline & 19/03/1885 & & All Powers agree in principle to provide joint guaranty for future $\mathrm{f} 9 \mathrm{~m}$ loan \\
\hline & 27/07/1885 & & Floating of bond in London \\
\hline \multirow[t]{4}{*}{ China 1895} & 04/06/1895 & 06/05-17/06 & \\
\hline & $7 / 06 / 1895$ & & Le Matin announces agreement for Chinese loan guaranteed by Russia \\
\hline & 29/11/1895 & $28 / 11-31 / 12$ & Franco-Chinese convention ceding a territory to France is presented to the French parliament for ratification \\
\hline & 19/07/1895 & & Floating of bond in Paris \\
\hline
\end{tabular}




\begin{tabular}{|c|c|c|c|}
\hline Case & Date & 95\% C.I. & Interpretation (from press) \\
\hline \multirow[t]{9}{*}{ Greece 1898} & 07/02/1898* & 19/01-01/03 & \\
\hline & 11/02/1898 & & Regarded as practically certain that the Greek indemnity loan would have joint guaranty of the three protecting powers \\
\hline & 10/07/1898 & & Floating of bond in London \\
\hline & 27/11/1898\# & $27 / 11-20 / 12$ & Representatives of the Great powers formally announces that King of Greece nominated as High Commissioner for Crete \\
\hline & 01/12/1898* & 01/12-26/01 & Announcement of the details of Greek public sector reforms \\
\hline & 24/01/1899* & $16 / 12-25 / 01$ & \\
\hline & 26/01/1899\# & 23/01-31/01 & Kyparissia Earthquake and reports of extensive economic damage \\
\hline & 18/07/1899\# & 17/06-19/07 & The Greek Parliament approves the military reform to be administered by British and German representatives. \\
\hline & 07/08/1899* & 23/07-30/08 & \\
\hline
\end{tabular}

Source: all information gathered from The Times, except when explicitly mentioned.

Notes: We used the sequential procedure in Bai and Perron (2003), i.e. after establishing that at least one structural break exists from the UD and MD statistics, we select the number of breaks by stopping at the last significant sup FT $(\mathrm{I}+1 \mid \mathrm{I})$ statistic. Dates in bold were not identified as structural breaks. + Breaks in $4 \%$ unified bond of 1880

¥ Breaks in $5 \%$ state domain bond of 1878 \# Breaks in $5 \%$ loan of $1881 *$ Breaks in 5\% loan of 1884 . 
Table 5: Long-term discount of guaranteed bonds

\begin{tabular}{lllllll}
\hline Sovereign & Period & Mean & Median & St. dev. & Max & Min \\
\hline \hline Ottoman Empire† & $1869-1894$ & 315.81 & 328.90 & 85.82 & 502.69 & 95.46 \\
Egypt & $1885-1907$ & 115.34 & 108.47 & 48.60 & 278.05 & 51.70 \\
China & $1895-1907$ & 161.11 & 166.43 & 28.27 & 228.87 & 75.75 \\
Greece & $1898-1907$ & 245.71 & 264.13 & 55.17 & 331.49 & 137.57 \\
\hline
\end{tabular}

texcluding the period in default (1876-81)

Table 6: Factor loadings and uniqueness

\begin{tabular}{lrrrr}
\hline Country & Bonds & Factor 1 & Factor 2 & Uniqueness \\
\hline \hline \multirow{6}{*}{ Turkey } & ygbr & 0.9144 & & 0.1639 \\
& yfra & 0.6967 & & 0.2290 \\
& y1855 & 0.8190 & & 0.2166 \\
& y1854 & 0.0982 & & 0.4447 \\
\hline \multirow{2}{*}{ Egypt } & ygbr & 0.9793 & -0.0558 & 0.034 \\
& yfra & 0.7481 & 0.6224 & 0.0396 \\
& y1885 & 0.9323 & 0.312 & 0.0267 \\
& ystate & 0.0676 & 0.9864 & 0.0146 \\
& yunif & 0.2087 & 0.9675 & 0.0127 \\
\hline \multirow{2}{*}{ China } & ygbr & 0.1478 & & 0.0418 \\
& yrus & 0.8253 & & 0.0387 \\
& y1895 & 0.8042 & & 0.0028 \\
& ycassel & 0.9865 & & 0.0265 \\
\hline \multirow{2}{*}{ Greece } & ygbr & 0.9863 & 0.1537 & 0.0024 \\
& yfra & 0.9421 & 0.3266 & 0.0033 \\
& yrus & 0.5296 & 0.7703 & 0.0657 \\
& y1898 & 0.9642 & 0.2595 & 0.0001 \\
& y1881 & 0.1744 & 0.9845 & 0.0003 \\
& y1884 & 0.2278 & 0.9734 & 0.0003 \\
\hline
\end{tabular}

Note: We chose the number of factors for each case from Kaiser's rule of retaining only factors with eigenvalues larger than 1 . The share of variance explained by the first factor was $87 \%$ in the Turkish case, $69 \%$ in the Egyptian, $80 \%$ in the Chinese and $76 \%$ in the Greek. 
Table 7: Variance decomposition of Turkish bonds

\begin{tabular}{lllll}
\hline & ygbr & yfra & y1855 & y1854 \\
\hline \hline ygbr & 0.9083 & 0.0210 & 0.0695 & 0.0013 \\
yfra & 0.5033 & 0.4321 & 0.0602 & 0.0044 \\
y1855 & 0.0658 & 0.0016 & 0.9296 & 0.0030 \\
y1854 & 0.0233 & 0.0362 & 0.0047 & 0.9359
\end{tabular}

Decomposition for 10 periods ahead.

Table 8: Variance decomposition of Egyptian bonds

\begin{tabular}{llllll}
\hline & ygbr & yfra & y1885 & ystate & yunif \\
\hline \hline ygbr & 0.8804 & 0.0253 & 0.0888 & 0.0039 & 0.0016 \\
yfra & 0.6663 & 0.1946 & 0.1253 & 0.0131 & 0.0006 \\
y1885 & 0.7269 & 0.0616 & 0.1975 & 0.0067 & 0.0073 \\
ystate & 0.4593 & 0.0556 & 0.1166 & 0.3643 & 0.0043 \\
yunif & 0.6791 & 0.1066 & 0.0617 & 0.0662 & 0.0865 \\
\hline
\end{tabular}

Decomposition for 10 periods ahead.

Table 9: Variance decomposition of Chinese bonds

\begin{tabular}{lllll}
\hline & ygbr & yrus & y1895 & ycassel \\
\hline \hline ygbr & 0.9983 & 0.0011 & 0.0001 & 0.0004 \\
yrus & 0.5150 & 0.4637 & 0.0212 & 0.0001 \\
y1895 & 0.7469 & 0.0611 & 0.1664 & 0.0256 \\
ycassel & 0.3964 & 0.0601 & 0.0526 & 0.4908 \\
\hline
\end{tabular}

Decomposition for 10 periods ahead.

Table 10: Variance decomposition of Greek bonds

\begin{tabular}{lllllll}
\hline & ygbr & yfra & yrus & y1898 & y1881 & y1884 \\
\hline \hline ygbr & 0.9959 & 0.0029 & 0.0006 & 0.0004 & 0.0000 & 0.0002 \\
yfra & 0.8766 & 0.1202 & 0.0000 & 0.0014 & 0.0005 & 0.0013 \\
yrus & 0.5079 & 0.0490 & 0.4069 & 0.0342 & 0.0010 & 0.0010 \\
y1898 & 0.9368 & 0.0397 & 0.0062 & 0.0163 & 0.0007 & 0.0003 \\
y1881 & 0.6142 & 0.0003 & 0.0004 & 0.0064 & 0.3514 & 0.0272 \\
y1884 & 0.6058 & 0.0000 & 0.0019 & 0.0061 & 0.3484 & 0.0378 \\
\hline
\end{tabular}

Decomposition for 10 periods ahead. 

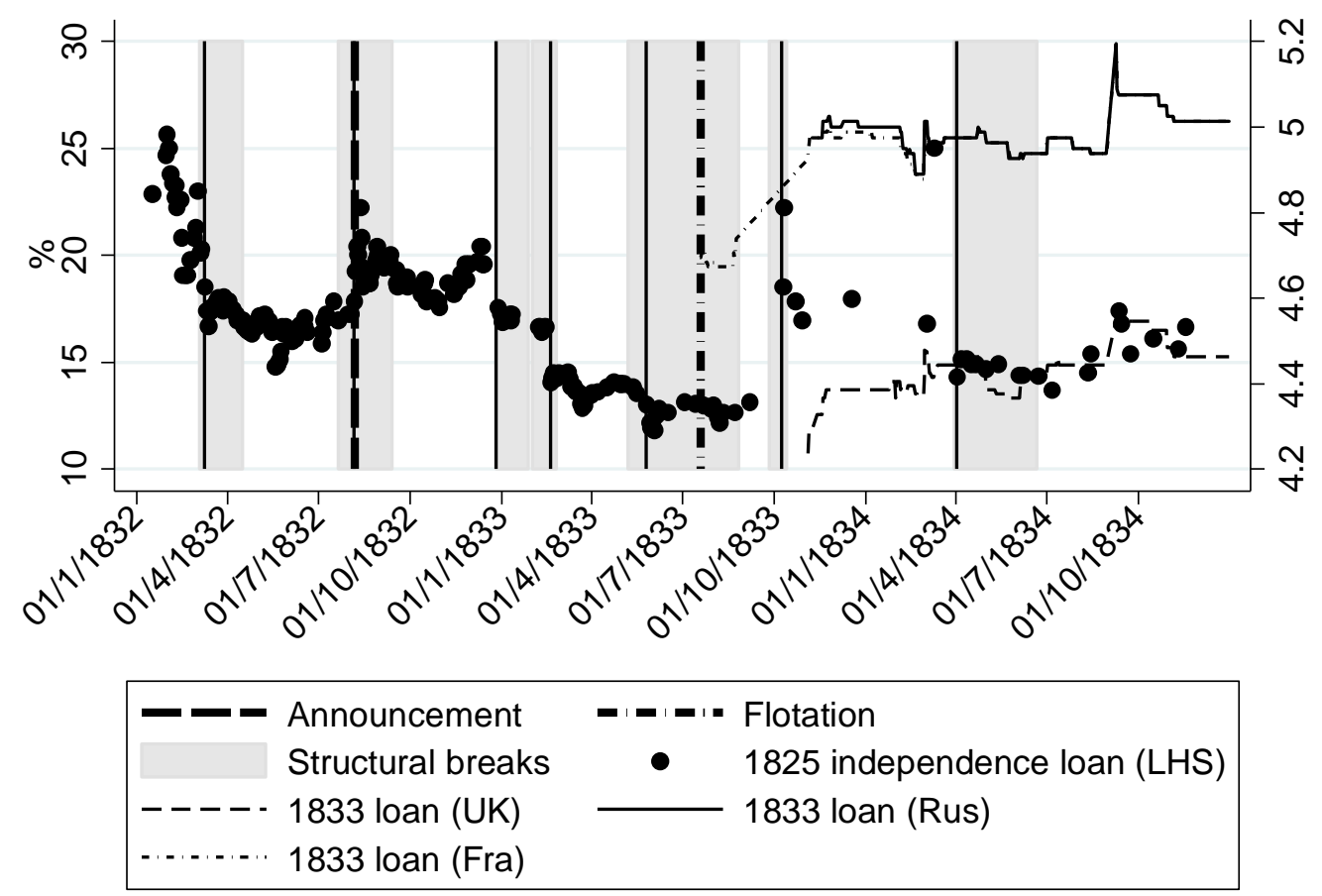

Structural breaks at 5\% significance with 95\% confidence intervals from Bai and Perron (2003)

Figure 2: Turkish bonds, 1854-56

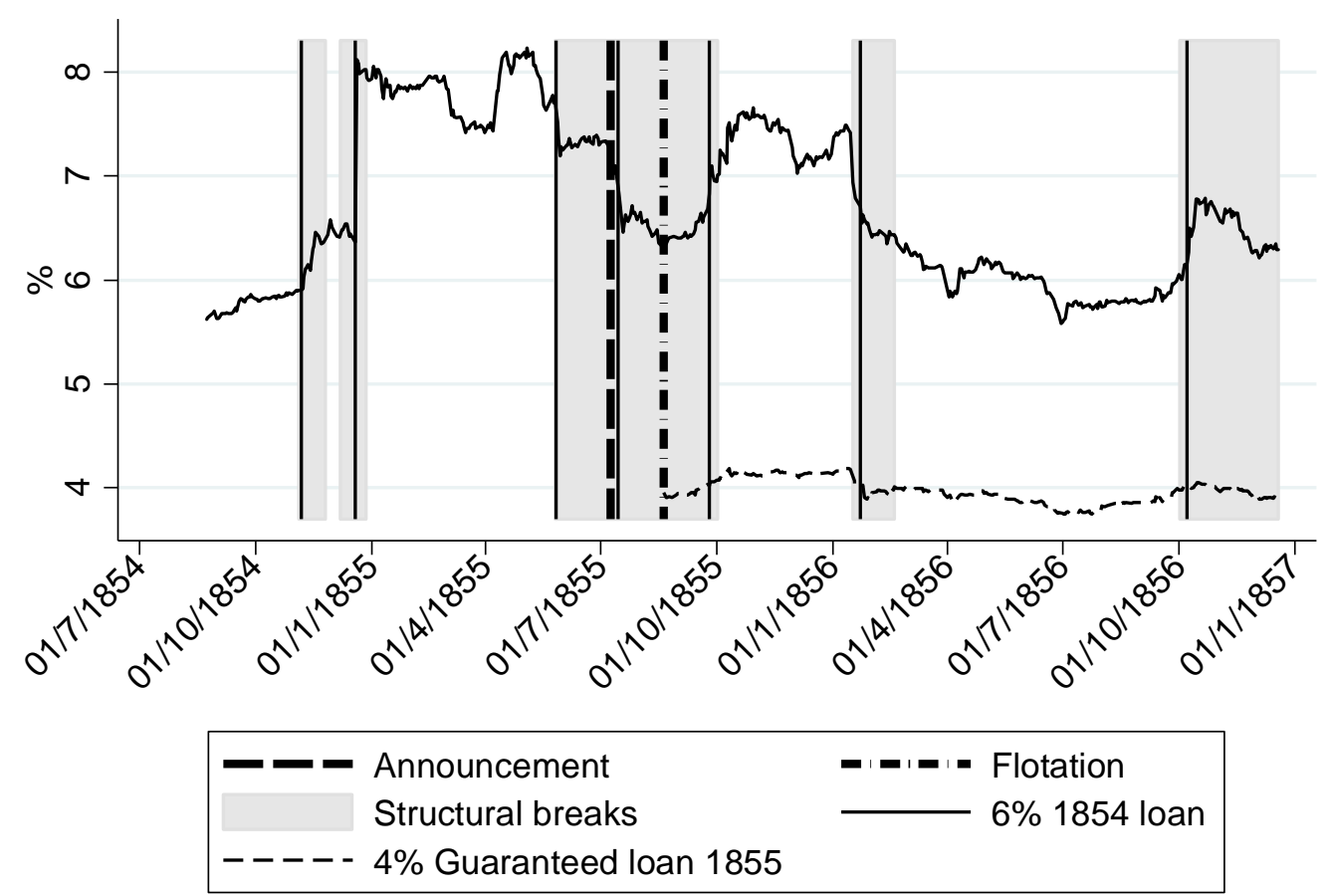

Structural breaks at $5 \%$ significance with $95 \%$ confidence intervals from Bai and Perron (2003) 
Figure 3: Egyptian bonds, 1884-85

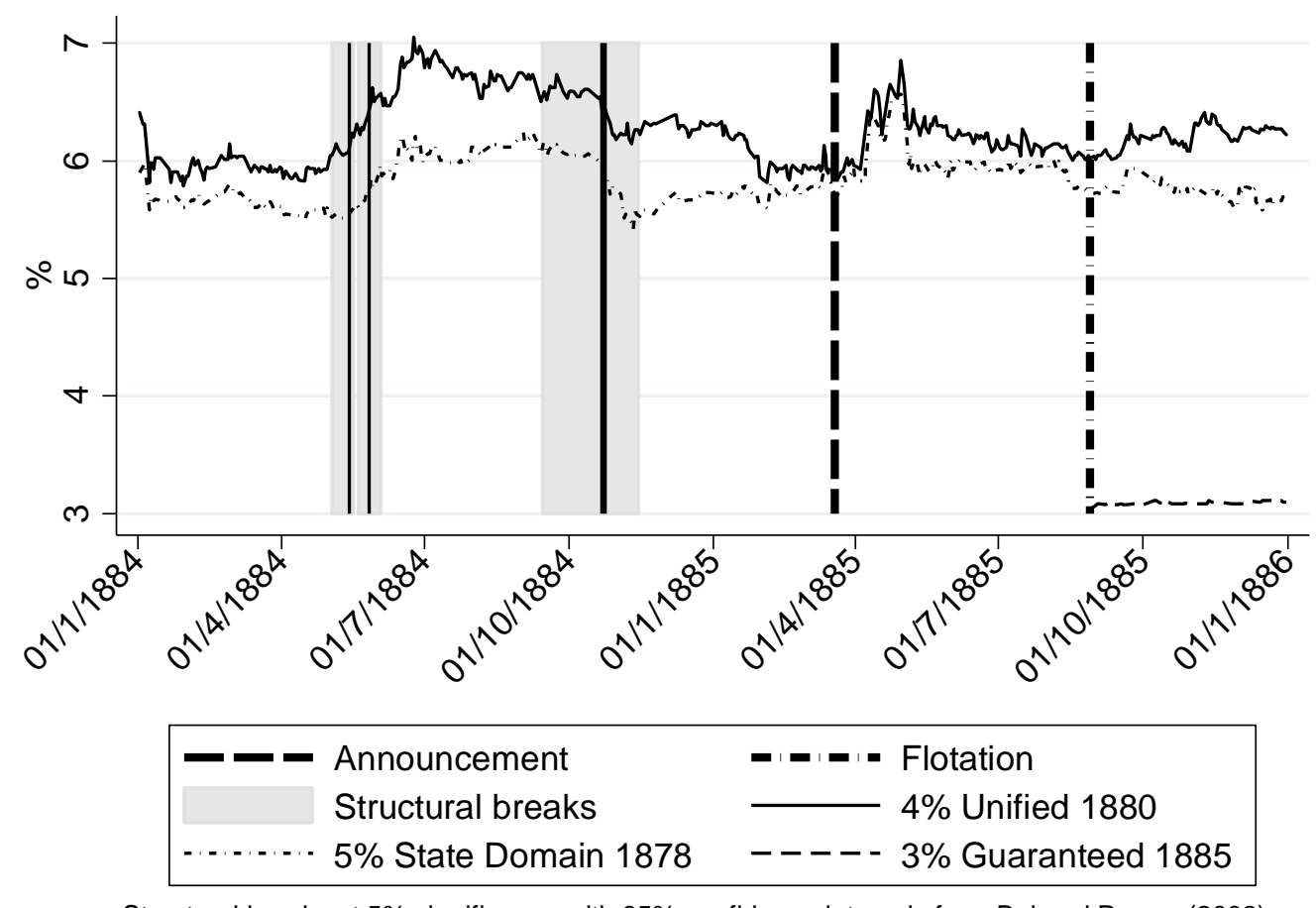

Structural breaks at 5\% significance with 95\% confidence intervals from Bai and Perron (2003)

Figure 4: Chinese bonds, 1895

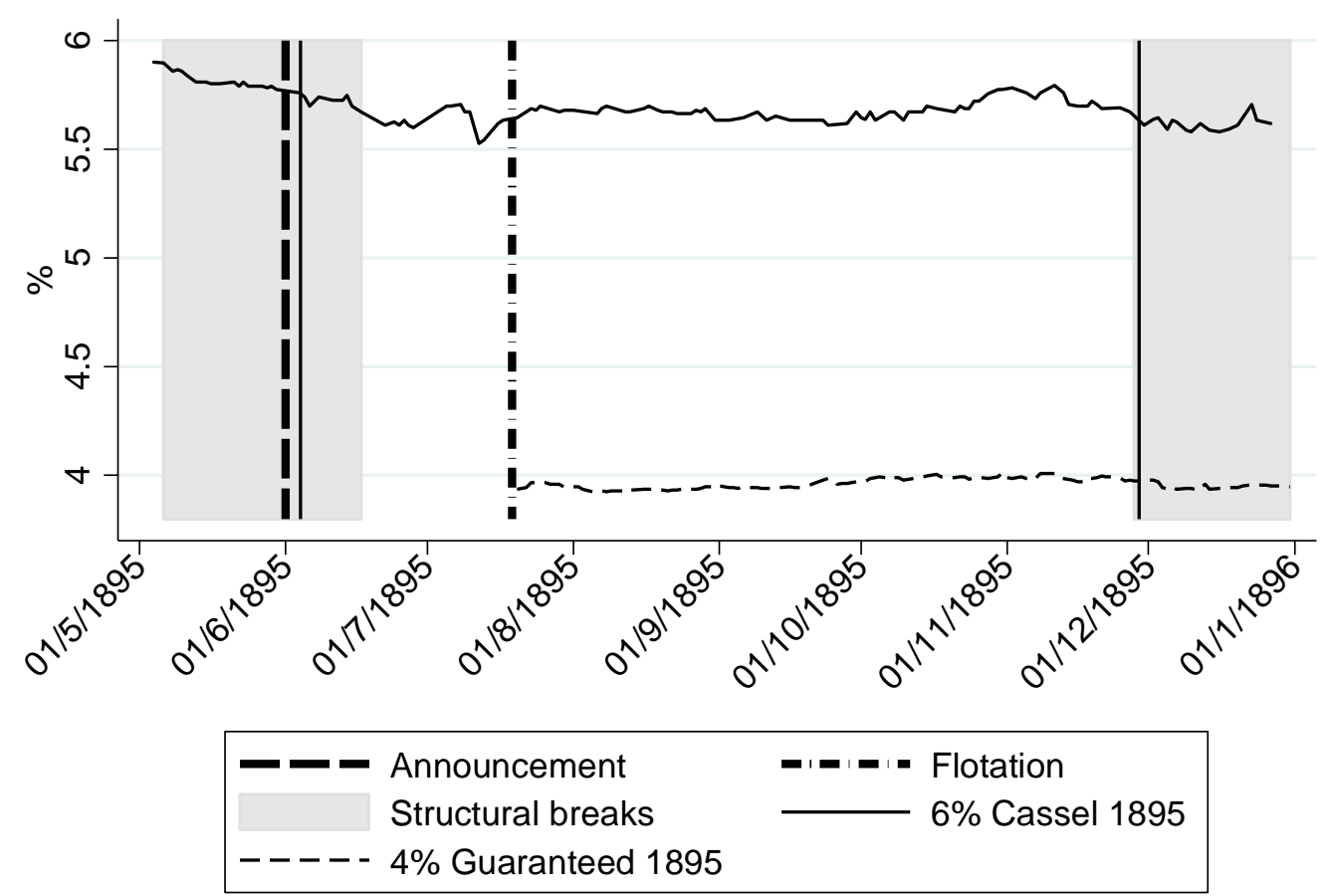

Structural breaks at $5 \%$ significance with $95 \%$ confidence intervals from Bai and Perron (2003) 
Figure 5: Greek bonds, 1898-99

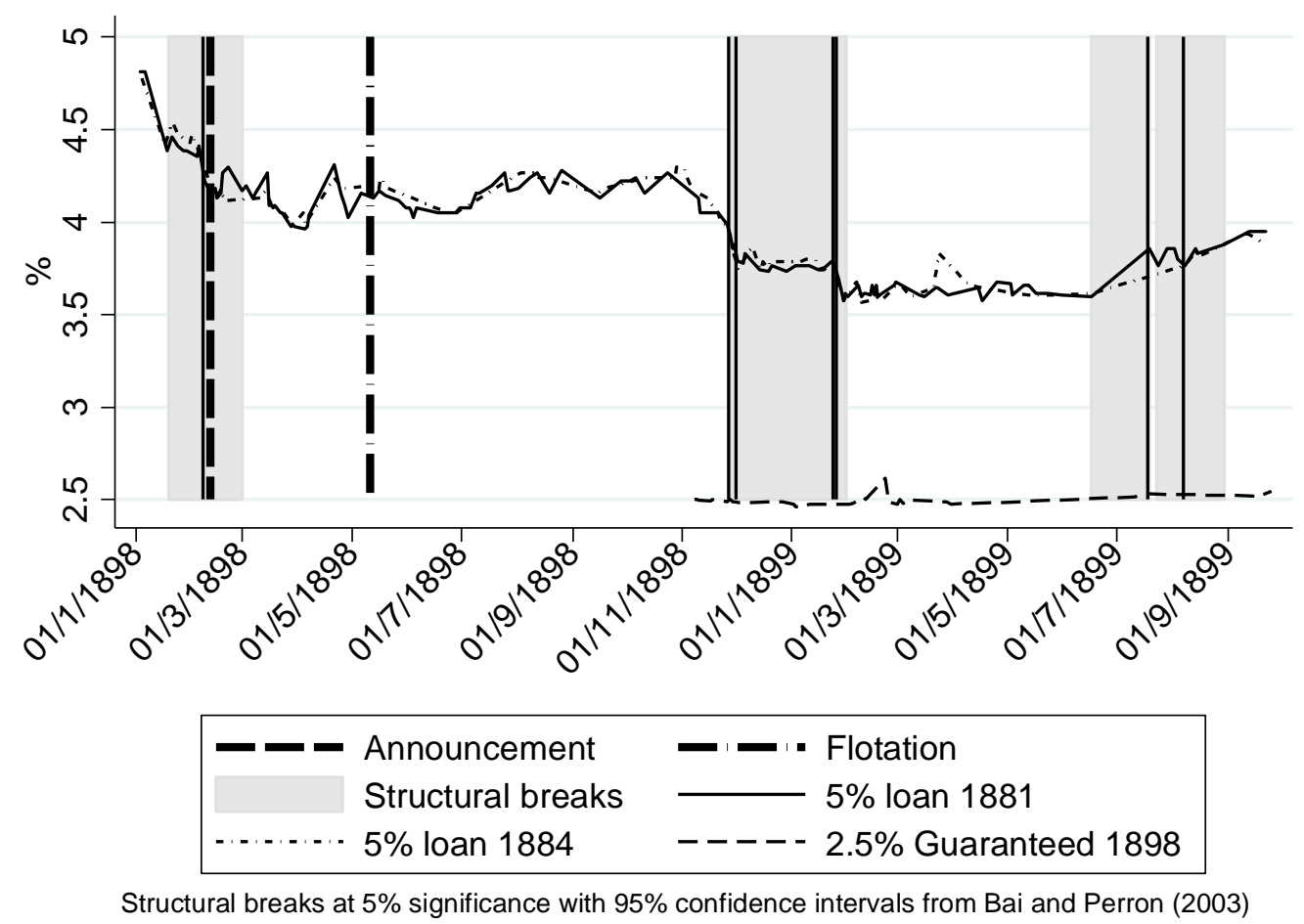

Figure 6: Long-term difference $r_{o}-r_{g}$
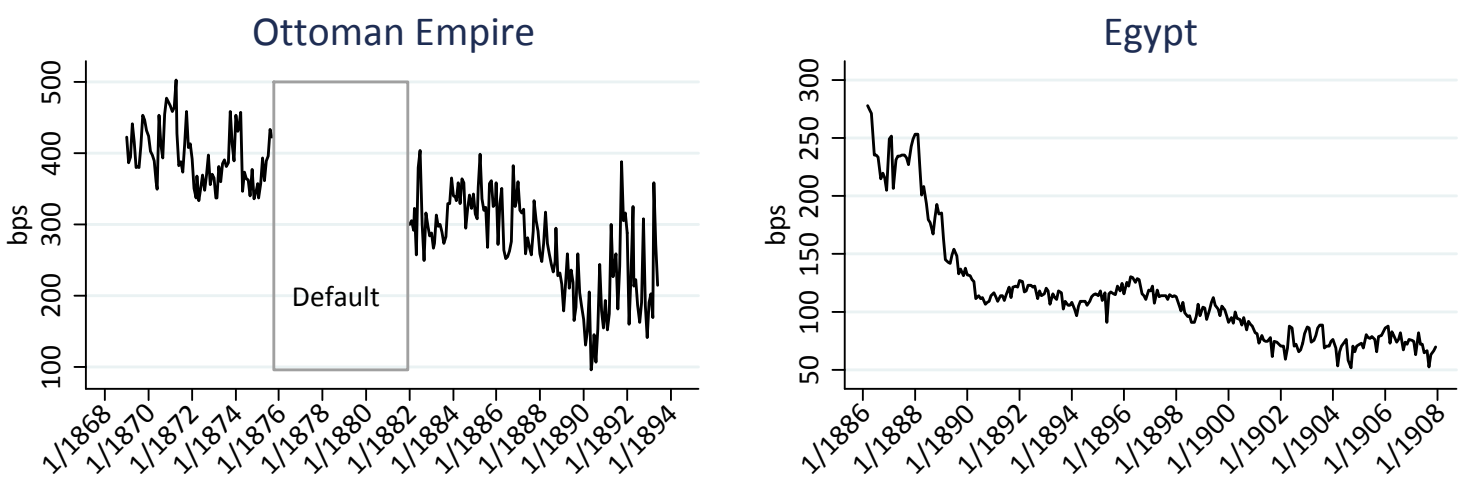

China
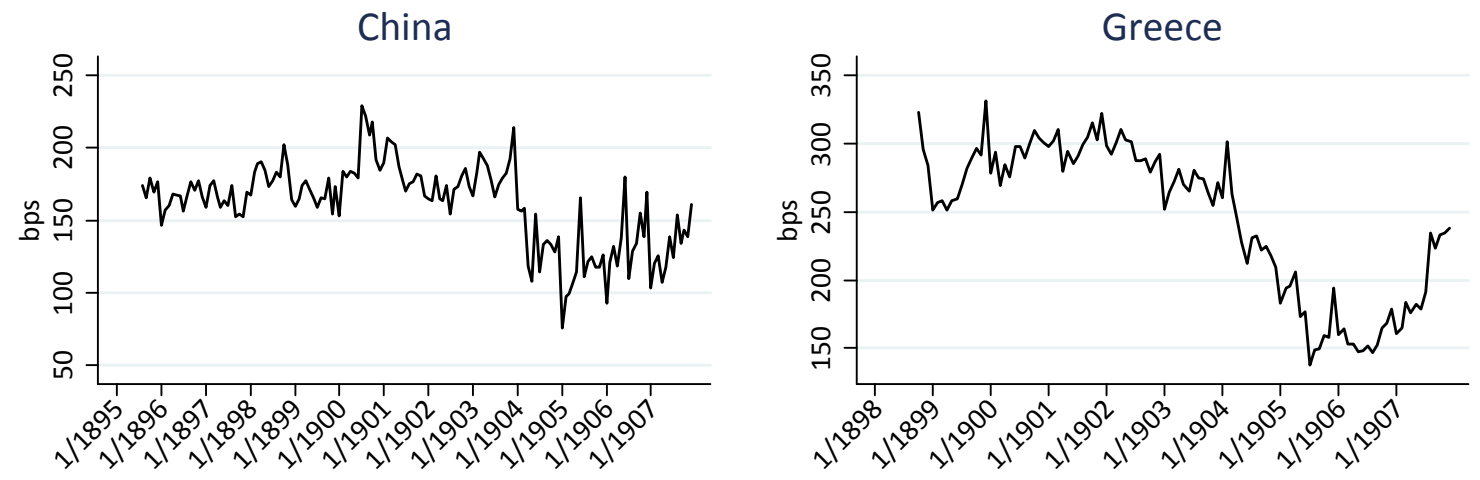
Figure 7: Factor loadings for Egypt and Greece
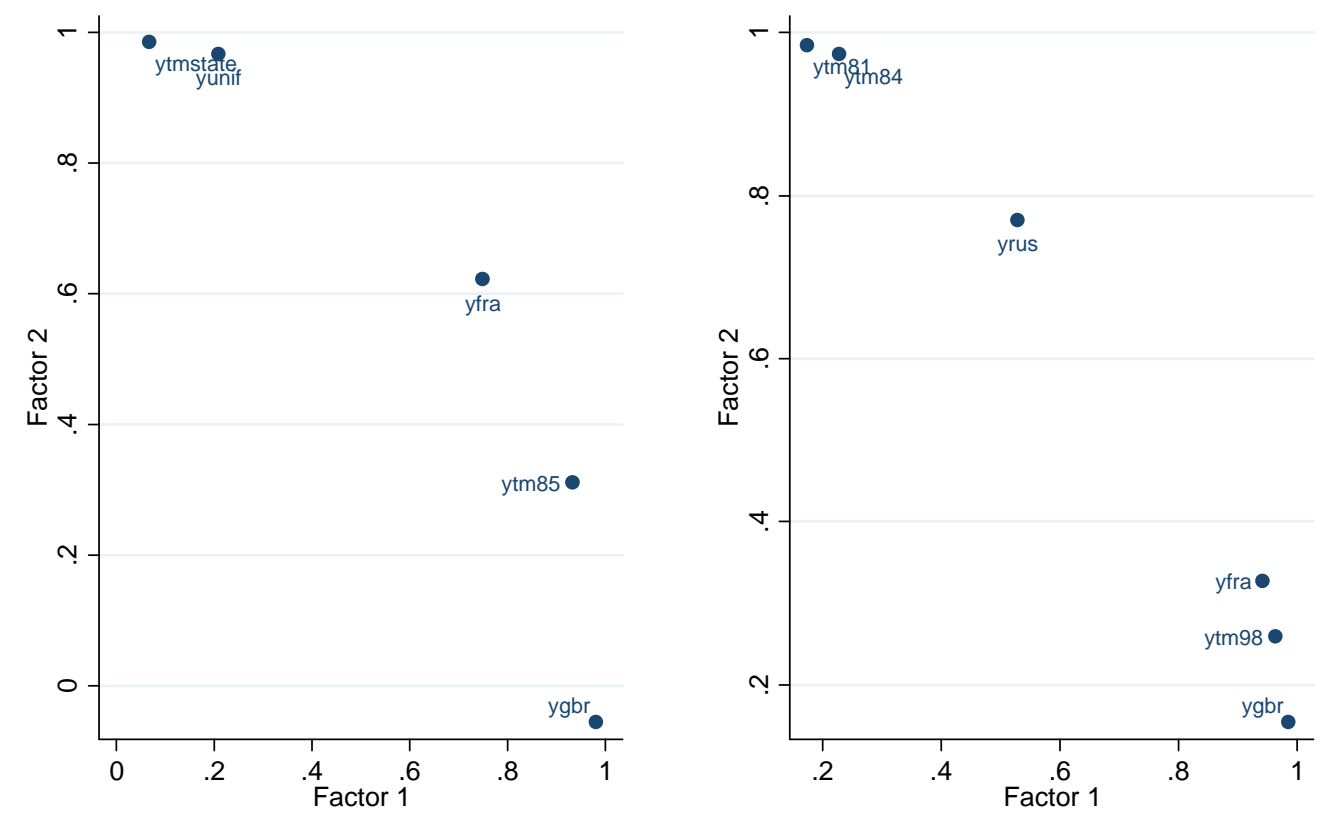

Rotation: orthogonal varimax Method: principal factors

Rotation: orthogonal varimax Method: principal factors

Left: Egypt, 1886-1907. Right: Greece, 1898-1907

\section{References}

\subsection{Primary Sources}

Bulletin de la Cote, Compagnie des agents de chance, accessed at http://www.gallica.fr

CFB, Council of the Corporation of Foreign Bondholders, Annual Reports, 1874-1914

HCH, House of Commons Hansard, 1803-1914

IMM, Investor's Monthly Manual, accessed at http://som.yale.edu/faculty-research/our-centersinitiatives/international-center-finance/data/historical-london

Tableau des titres cotés à la Bourse de Paris, Direction générale de l'enregistrement, des domaines et du timbre.

Times Digital Archive 1785-2006, Farmington Hills, Mich.: Thomson-Gale. 
The Economist Historical Archive, 1843-2007, Gale Group.

The Course of the Exchange, 1832-1899, London, Guildhall Library.

\subsection{Secondary Sources}

Accominotti, O. et al. (2010) “Black Man's Burden, White Man's Welfare: Control, Devolution and Development in the British Empire, 1880-1914," European Review of Economic History 14(1): 4770.

Aizenman, J., M. Hutchison and Y. Jinjarak (2013) "What is the risk of European sovereign debt defaults? Fiscal space, CDS spreads and market pricing of risk" Journal of International Money and Finance 34: 37-59.

Andreades, A. (1925) Les contrôles financiers internationaux, Paris: Librairie Hachette.

Arellano, M. and S. Bond. (1991) "Some tests of specification for panel data: Monte Carlo evidence and an application to employment equations," Review of Economic Studies, 58(2): 277-297.

Arellano, M. and O. Bover (1995) "Another look at the instrumental variable estimation error component models," Journal of Econometrics, 68(10): 29-51.

Bai, J. and P. Perron (1998) "Estimating and testing linear models with multiple structural changes," Econometrica 66: 47-78.

Bai, J. and P. Perron (2003) "Computation and analysis of multiple structural change models," Journal of Applied Econometrics 18: 1-22.

Beirne, J. and M. Fratzsche (2013) "The pricing of sovereign risk and contagion during the European sovereign debt crisis" Journal of International Money and Finance 34: 60-82.

Bernoth, K., J. Hagen and L. Schuknecht (2012) "Sovereign risk premiums in the European government bond market" Journal of International Money and Finance 31(5): 975- 995.

Barclays Capital Economic Research (2011) "Euro Themes, A proposal to restore euro area stability," 18 August 2011.

Beck, T., W. Wagner and H. Uhlig (2011) "Insulating the financial sector from the European debt 
crisis: Eurobonds without public guaranties," VoxEU, 17 September.

Bofinger, P. et al. (2011) “A European Redemption Pact," VoxEU, 11November.

Bolton, P. and O. Jeanne (2009) "Structuring and Restructuring Sovereign Debt: The Role of Seniority," Review of Economic Studies 76: 879-902.

Brunnermeier, M., L. Garicano, P. Lane, M. Pagano, R. Reis, T. Santos, S. van Nieuwerburgh, and D. Vayanos (2011) “ESBies: A realistic reform of Europe's financial architecture,” VoxEU, 25 October. Campbell, J., A. Lo and A. MacKinlay (1997) The Econometrics of Financial Markets, Princeton: Princeton University Press.

Chavaz, M. and M. Flandreau (2015) "High and dry': the liquidity and credit of colonial and foreign government debt in the London Stock Exchange (1880-1910)" Bank of England Staff Working Paper No. 555.

Choi, I. (2001) "Unit root tests for panel data," Journal of International Money and Finance, 20: 249272.

Claessens, S., A. Mody and S. Vallée (2012) “Paths to Eurobonds," IMF Working Paper 12/172.

Clay, C. (2000) Gold for the Sultan. Western Bankers and Ottoman Finance 1856-1881. New York: I. B. Tauris.

Collet, S. (2013) "A unified Italy? Sovereign debt and investor scepticism" ESCP: Mimeo.

Colvin, A. (1905) The Making of Modern Egypt (1881-1905). London: Seeley.

De Grauwe, P. and W. Moesen (2009) "Gains for all: a proposal for a common euro bond," Intereconomics, May/June: $132-135$.

Delors, J. (1989) "Report on Economic and Monetary Union in the European Community," presented April 17, 1989 by Committee for the Study of Economic and Monetary Union.

Delpla, J. and J. von Weizsäcker (2010) “The Blue Bond Proposal," Breugel Policy Briefs 420, Bruegel, Brussels.

Denby, C. (1916) "The National Debt of China-Its Origin and Its Security," Annals of the American Academy of Political and Social Science, 68: 55-70. 
Detragiache, E. (1994) "Sensible Buybacks of Sovereign Debt", Journal of Development Economics 43, 317-333.

Dübel, H.-J. (2011) “Partial Sovereign Bond Insurance by the Eurozone: A More Efficient Alternative to Blue (Euro-)bonds," CEPS Policy Brief No. 252.

Eichengreen, B. and A. Mody (2000) "Lending Booms, Reserves, and the Sustainability of Short-Term Debt: Inferences from the Pricing of Syndicated Bank Loans," Journal of Development Economics, 63(1): 5-44.

Eijffinger, S., M. Kobielarz and B. Uras (2015) "Sovereign Debt, Bail-Outs and Contagion in a Monetary Union" CEPR Discussion Paper \#10459.

EPDA/SIFMA (2008) “Towards a Common European T-bill," Briefing Note March 2009.

Esteves, R. (2013) "The Bondholder, the Sovereign, and the Banker. Sovereign Debt and Bondholders' Protection Before 1914," European Review of Economic History, 17 (4): 389-407.

European Commission (2011) "Green Paper on the Feasibility of Introducing Stability Bonds," November 23.

Favero, C. and A. Missale (2011) "Sovereign Spreads in the Euro Area. Which Prospects for a Eurobond?” CEPR Discussion Paper \#8637.

Feng-Hua H. (1919) Public Debts in China, New York: AMS Press.

Flandreau, M. (2013) "Sovereign states, bondholders committees, and the London Stock Exchange in the nineteenth century (1827-68): new facts and old fictions" Oxford Review of Economic Policy 29 (4): 668-696.

Flandreau, M. and F. Zumer (2004) The Making of Global Finance, 1880-1913, Paris: OECD.

Ghosh, A., J. Ostry and M. Qureshi (2013) "Fiscal space and sovereign risk pricing in a currency union" Journal of International Money and Finance 34: 131-163.

Gros, D. (2010) "The Seniority Conundrum. Bail out countries but bail in private, short-term creditors?" CEPS Commentary, 6 December 2010, Brussels: Centre for European Policy Studies.

Gros, D. (2011) “Eurobonds: Wrong Solution for Legal, Political, and Economic Reasons," VoxEU, 24 
August.

Hatchondo, J., L. Martinez and C. Padilla (2012) "Debt dilution and sovereign default risk" FRB Richmond Working Paper 10-08R.

Holtz-Eaking, D., W. Newey and H. Rosen (1988) "Estimating Vector Autoregressions with Panel Data," Econometrica, 56(6): 1371-1395.

Issing, O. (2009) "Why a Common Eurozone Bond Isn't Such a Good Idea," White Paper No. 3, Centre for Financial Studies, Frankfurt.

Jeze, G. (1924) La garantie des emprunts publics d'Etat, Paris.

Jones, E. (2010) “A Eurobond Proposal to Promote Stability and Liquidity while Preventing Moral Hazard," ISPI Policy Brief No 180, March.

Kofas, J. V. (1981) Financial Relations of Greece and the Great powers, 1832-1862, New York: Columbia University Press.

Kopf, Christian (2011) "Restoring Financial Stability in the Euro Area," CEPS Policy Brief No. 237, 15 March 2011.

Levandis, J. A. (1944) The Greek Foreign Debt and the Great powers, 1821-1898, New York: Columbia University Press.

Mitchener, K. and M. Weidenmier (2010) "Supersanctions and Sovereign Debt Repayment," Journal of International Money and Finance 29: 19-36.

Muellbauer, J. (2013) "Conditional Eurobonds and the Eurozone Sovereign Debt Crisis," Oxford Review of Economic Policy 29 (3): 610-45.

Pamuk, Ş. (1978) Foreign Trade, Foreign Capital and the Peripheralization of the Ottoman Empire 1830-1913, PhD thesis, University of California, Berkeley.

Serbos, S. "Eurozone's Debt Crisis and US Strategy: A Return of Geopolitics for Europe," Johns Hopkins: Transatlantic Partnership Forum Working Paper Series.

Tsebelis, G. (2015) "Lessons from the Greek Crisis," Journal of European Public Policy, http://dx.doi.org/10.1080/13501763.2015.1087215. 
Tuncer, A. C. (2015) Sovereign Debt and International Financial Control: the Middle East and the Balkans, 1870-1914. London: Palgrave Macmillan.

Varoufakis, Yanis and Stuart Holland (2011) "A Modest Proposal for Overcoming the Euro Crisis," Levy Economics Institute of Bard College, Policy Note 2011/3.

Viner, J. (1928) "Political Aspects of International Finance" The Journal of Business of the University of Chicago, 1(3): 324-363.

Wynne, W. (1951) State Insolvency and Foreign Bondholders. Vol. II Selected Case Histories of Governmental Foreign Bond Defaults and Debt Readjustments, Yale: Yale University Press.

Yackley, J. (2013) Bankrupt: Financial Diplomacy in the Late Nineteenth-Century Middle East, PhD thesis, University of Chicago. 


\section{Appendix}

This Appendix serves three purposes. A first section describes the choices we made to select the bonds used in the analysis and compute their yields. The next two sections then reveal the full results of the event studies mentioned in section 4.2 of the manuscript, as well as of the panel VARs of section 4.3 .

\section{A.1. Yields}

This Appendix describes the choices we made to select the bonds used in the analysis and compute their yields. The choice of comparator bonds was guided by two principles. First, for the nonguaranteed bonds, we identified the most liquid issues outstanding at the time of the introduction of the guaranteed bonds. In particular, we only considered external bonds regularly quoted in London or Paris. This should minimise any differences in liquidity premia between $r_{g}$ and $r_{o}$ but, more importantly, it should give as close a measure as possible of the marginal cost of funding for the sovereign before and after the new issue. Second, for the guaranteeing powers, we chose the benchmark issues, for similar reasons, but paying attention to avoid the effect of expected imminent conversions on the simple yields of bonds (as described in Flandreau and Zumer 2004).

We tried three definitions for yields. First we used the Investors Monthly Manual (IMM) own estimate of the simple yields (coupon/ price). The IMM was a likely port of call for contemporary investors, so that by using its yield data we will be approaching more closely the market's appreciation of the return on each bond. As a second alternative we calculated the yield-to-maturity (YTM), from the prices reported in IMM and the redemption schedule of each bond. As a final alternative we tried to price in the callable options implicit in the majority of the bonds by calculating their yields-to-call (YTC). As an example of the impact of these different definitions, we reproduce in Figure A.1 the yields of the Egyptian guaranteed bond of 1885 .

Figure A.1 here

As the market price of this bond hovered above par for almost the whole period, the simple yield was below the coupon (3\%). Although this bond had a long maturity (41 years), there will be a difference between the simple yields and the YTM. Because of the pricing above par, the YTM is usually smaller than the simple yield. Finally, for the same reason, the YTC is also below the two other yields, as prices above par would lead investors to anticipate a conversion into a lower coupon bond. Conversely, the YTC rose above the simple yield whenever the bonds traded at a discount.

From the two problems with using simple yields -maturity differences and anticipation of calls-, we think that the first is the overriding consideration for two reasons. First, there is sufficient variation in the maturities of the bonds to warrant caution in using simple yields that assume all bonds to be close to perpetuities. Non-guaranteed bonds had shorter maturities than the guaranteed loans and were priced below par most of the time. For discount bonds, the YTM decreases with maturity, such that simple yields (implying an infinite maturity) are lower than the true YTM. And since nonguaranteed bonds had shorter maturity to run than the guaranteed loans, using simple yields would bias down our estimates of the discount of guaranteed bonds ro-rg. 
In second place, we believe that the YTC is less appropriate for the bonds we are considering. As mentioned, the non-guaranteed bonds usually traded at a discount, such that investors would not worry about their imminent conversion (in fact, not one of these bonds was converted). Likewise, the guaranteed bonds were never converted into lower coupon bonds, despite the fact that they traded above par for long periods. Hence, YTC would be higher than YTM for non-guaranteed bonds and lower for guaranteed bonds. The result would be a bias up of our estimates of ro-rg. Between the upward bias from using simple yields and the downward bias of YTC, we conservatively chose the middle option of using the YTM.

\section{A.2. Event studies}

As a final test of the dilution hypothesis, we conducted an event study. We follow the standard methodology in event study analysis, although hampered by the lack of a high frequency market benchmark. As we do not have a daily return index of the relevant market (sovereign bonds), we use a simpler model that assumes a bond-specific constant returns model. The cumulated abnormal returns around the event window are therefore defined relative to the bond-specific average return in the estimation window. This model has a weaker power than a properly specified market model, but we are forced to use it for lack of data. Also, to prevent clustering bias we need that the returns of the individual securities are uncorrelated in the cross section. A simple solution is to make sure the event windows do not overlap across securities, which we accomplish by dropping two of the repeated comparator bonds. The final portfolio for the analysis includes 5 bonds - the $5 \%$ Greek 1825, the 6\% Turkey 1854, the 4\% Egypt unified 1880, the 6\% Chinese Cassel and the 5\% Greek 1881.

We experimented with four different test statistics (Campbell, Lo and MacKinlay 1997). The first two differ in the method for aggregating cumulated abnormal returns (CAR) across securities. The first statistic $\left(J_{1}\right)$ simply takes the average of CAR across securities, i.e., with $N$ securities and an event window between dates $t_{1}$ and $t_{2}$, the test statistic is:

$$
J_{1}=\frac{\frac{1}{N} \sum_{i} \widehat{C A R}_{i}\left(t_{1}, t_{2}\right)}{\frac{1}{N} \sum_{i} \hat{\sigma}_{i}} \stackrel{d}{\rightarrow} \mathcal{N}(0,1)
$$

where the terms $\hat{\sigma}_{i}$ are the usual OLS estimators of the variance of the error term. Since we use nonoverlapping events windows, the variance of the denominator is the simple average of the $\hat{\sigma}_{i}$ estimates. The second test aggregates instead the CAR normalised by the estimators of variance:

$$
J_{2}=\frac{1}{N} \sum_{i} \widehat{\operatorname{SCAR}}_{i}\left(t_{1}, t_{2}\right) \stackrel{d}{\rightarrow} \mathcal{N}(0,1)
$$

where $\widehat{\operatorname{SAR}}_{i}\left(t_{1}, t_{2}\right)=\widehat{\operatorname{CAR}}_{i}\left(t_{1}, t_{2}\right) / \hat{\sigma}_{i}$. These statistics also differ in the counterfactual: if the CAR are higher for securities with higher variance then statistic $J_{1}$, which gives equal weight to the CAR of each bond, should be used. If the true CAR is the same across securities, then $J_{2}$ has greater power. Since it is unclear which of these applies to the bonds under study, we report the values of both $J_{1}$ and $J_{2}$. A different way of distinguishing between true CAR and increased variance during the event 
window is to use cross-sectional estimates of the variances of the two test statistics that do not rely on the time-series estimates based on the estimation window. ${ }^{1}$ We also report the two test statistics with these variances under $J_{1 \text { cs }}$ and $J_{2 c s}$.

The two final statistics use non-parametric evidence. $J_{3}$ is based on the sign of the CAR. Under the alternative hypothesis that the probability of positive CAR during the event is $1 / 2$, the test statistic is:

$$
J_{3}=\left(\frac{T^{+}}{T}-\frac{1}{2}\right) \frac{\sqrt{T}}{1 / 2} \stackrel{d}{\rightarrow} \mathcal{N}(0,1)
$$

where $T^{+}(T)$ is the number of positive CAR (all possible cases). If the distribution of CAR is skewed, the expected proportion of positive returns will deviate from $50 \%$ and in that case a rank test is preferred. If $K_{i t}$ is the rank of the CAR of bond $i$ on date $t$ (with $t=0$ defining the event date), then the test statistic is:

$$
\begin{aligned}
J_{4} & =\frac{1}{N} \sum_{i}\left(K_{i 0}-\frac{T+1}{2}\right) / s \stackrel{d}{\rightarrow} \mathcal{N}(0,1) \\
s & =\sqrt{\frac{1}{T} \sum_{\tau=1}^{T}\left[\frac{1}{N} \sum_{i}\left(K_{i \tau}-\frac{T+1}{2}\right)\right]^{2}}
\end{aligned}
$$

where $(T+1) / 2$ is the expected rank of an event window with $T$ days. Table A.1 collects the values of the six statistics for three lengths of the estimation window $(15,20$ and 30 days) and using only pre-event windows or bilateral windows, around the event window. ${ }^{2}$

\section{Table A.1 here}

The usual assumption in this literature is that although published on a given day, the information contained in the announcement could have been public the day before (essentially because of printing lags of newspapers). Hence, the length of the event window is first set at two days. However, we are unsure about the power of this test, because the size of the portfolios is small ( 5 bonds) and also because we cannot be sure that the information was not available more than a day prior to publication. Hence, as an alternative, we define the announcement period by the $95 \%$ confidence intervals of the breakpoints closer to the date when the guaranteed bonds were first published by the press (see Table 1 in the manuscript).

The results of the event studies are not entirely consistent across the different test statistics. Nevertheless, the preponderance of evidence is that the announcement of guaranteed bonds had no significant impact on the returns of legacy bonds or, in fact, had a positive effect. This is consistent with the graphical impression from Figures 2-5 in the manuscript, which already confirmed that the issue of guaranteed bonds stabilised, rather than diluted, the market for legacy debt, with the exception of the first Greek operation. In particular, the parametric tests $\left(J_{1}\right.$ and $\left.J_{2}\right)$ over short windows ( 2 days) point out for a positive and significant impact of the guaranteed bonds. This is not a figment of increased variance after the announcement, since the results hold even stronger for the

\footnotetext{
${ }^{1}$ Details in Campbell, Lo and MacKinlay (1997).

2 I.e., the 'before' statistics are based on estimates 15,20 , or 30 days before the event, whereas the 'bilateral' values use estimates from windows 15,20 or 30 days before and after the event.
} 
variant of the test statistics with cross-sectional variances $\left(J_{1 c s}\right.$ and $\left.J_{2 c s}\right)$, which implies that the events were associated not only with positive abnormal returns but also with lower variance. The results are also stronger for longer estimation windows. The non-parametric tests are less sanguine for short event windows, but still support positive and significant effects for the third test statistic. However, the more robust statistic $\mathrm{J}_{4}$ already implies a dilution effect.

The evidence for the longer event windows (corresponding to the confidence intervals of the BaiPerron breakpoints) is more mixed and there is now more support for dilution effects, especially when using longer estimation windows, and also when using bilateral rather than unilateral windows. ${ }^{3}$ Nonetheless, if the tests with short even windows probably have low power, some of the event windows based on the Bai-Perron tests are so long that we may be incurring in the reverse type I error. Indeed, the longest event window in this case, for the 1832-33 Greek operation, has 55 days. $^{4}$

A conservative conclusion from this analysis must therefore be that, though possibly present, there is no strong evidence of dilution effects in the cases studied in this paper. The first Greek bond of 1833 comes closer to a case of dilution, but even here only for a short while, as illustrated by the fast reversal of yields on the 1825 independence bonds after the initial announcement shock (Figure 1 in the manuscript).

\section{A.3. Panel VARs}

Panel VARs combine the traditional VAR approach, which treats all the variables in the system as endogenous, with the panel-data approach, which allows for unobserved individual country heterogeneity. We specify a first-order VAR model as follows:

$$
Y_{i t}=\Gamma_{0}+\Gamma(L) Y_{i t}+v_{i}+\varepsilon_{i t}
$$

where $Y_{i t}$ is a vector of endogenous variables (bonds yields), $\Gamma_{0}$ is a vector of constants, $\Gamma(L)$ is a matrix polynomial in the lag operator, $v_{i}$ is a matrix of country-specific fixed effects, and $\varepsilon_{i t}$ is a vector or error terms (with zero mean and country-specific variance).

However, the correlation between the fixed effects and the regressors due to lags of the dependent variables implies that the commonly used mean-differencing procedure creates biased coefficients (Holtz-Eaking et al. 1988). This drawback can be avoided by a two-step procedure. First, we use the "Helmert procedure", that is, a forward mean-differencing approach that removes only the mean of all future observations available for each country-year (Arellano and Bover 1995). ${ }^{5}$ Second, we estimate the system by GMM and use the lags of the regressors as instruments, as the transformation keeps the orthogonality between lagged regressors and transformed variables

\footnotetext{
${ }^{3}$ Contrary to the studies with short event studies, the variance during the events is now higher than in the estimation windows, such that the $\mathrm{J}_{1 \mathrm{cs}}$ and $\mathrm{J}_{2 \mathrm{cs}}$ are now smaller than $\mathrm{J}_{1}$ and $\mathrm{J}_{2}$, respectively.

${ }^{4}$ The corresponding windows for the other events have 14 days (Turkey), 32 (Egypt), 43 (China) and 42 (second Greek bond).

${ }^{5}$ That is, for bond $i$ and time $t$, the Helmert transformation is given by $\tilde{y}_{i t}=\left(\frac{T_{i}-t}{T_{i}-t+1}\right)^{1 / 2}\left(y_{i t}-\frac{\sum_{\tau=t+1}^{T_{i}} y_{i \tau}}{T_{i}-\tau}\right)$.
}

We also tried simply time-differencing the yields and the results were similar. 
unchanged (Arellano and Bond 1991). In our model, the number of regressors is equal to the number of instruments. Consequently, the model is "just identified" and the system GMM is equivalent to estimating each equation by two-stage least squares. We tested all transformed variables for unit roots by using a Fisher-type test that allows for large T-small N panels (Choi 2001) and could reject them for all panels.

Another issue that deserves attention refers to the impulse-response functions. Given that the variance-covariance matrix of the error terms may not be diagonal, we need to decompose the residuals so that they become orthogonal. We follow the usual Choleski decomposition that order variables such that any potential correlation between the residuals of two elements is allocated to the variable that comes first. In all cases we ordered the bonds of guaranteeing powers first, starting with Great Britain and following with France and Russia. Because of the nature of international guaranties, we ordered the guaranteed bonds second, and the non-guaranteed domestic bonds last. We also experimented with different orderings within these three groups of bonds, where possible, but the results did not differ materially. Finally, given the relatively low frequency of the data, we only ran the models with one monthly lag. The results are described in Table A.2, which lists the four models horizontally, i.e. each row identifies a left-hand side variable and the coefficients of the lags of itself and the other endogenous variables (listed in the columns), as appropriate.

\section{Table A.2 here}

With the exception of Greece, the models are almost diagonal. This is understandable given the low frequency of the data, which makes it harder to identify lagged effects of yield changes on to other bonds' yields. This structure appears consistent with the ordering of the bonds, which is also confirmed by the impulse response functions (IRF) that come out of this exercise. These are represented in Figures A.2-A.5 for up to six months, with 95\% confidence intervals computed from Monte Carlo simulations.

\section{Figures A.2-A.5 here}

Despite the low data frequency, the IRFs are consistent with the ordering of the variables in the PVARs in the sense that the variables ordered first do not respond to shocks to variables ordered later. For instance, the yields of British long-term bonds (consols), arguable the world benchmark, do not react to any other yields in the systems. French yields only react to shocks to British yields, and so on. In general, a shock to British yields has positive and long-lasting effects on all other bonds, which is in accordance with their benchmark status. The size of the effects is consistently below one, meaning that increases in the benchmark yield actually narrowed spreads, as has been found elsewhere (Eichengreen and Mody 2000). However, this can also be driven by the monthly frequency of the data, as most of the adjustment to a shock to British bonds might happen faster than after a month. ${ }^{6}$

Shocks to the yields of other guaranteeing powers had permanent effects on guaranteed bonds but, generally, not on other domestic bonds. Or, when the impacts are statistically significant, they are either very small in economic terms (e.g. the IRF of the two Egyptian bonds-unified and state domain-to shocks to French yields) or non-persistent, as in the reactions of the Turkish and Greek

\footnotetext{
${ }^{6}$ This would be consistent with Uribe and Yue's (2006) model of overshooting spreads.
} 
non-guaranteed bonds to shocks to French or Russian yields. The size of the reactions of the yields of guaranteed bonds was also consistent with the ordering of the guaranteeing powers, being larger in the IRF to shocks to British yields than to French and Russian. This then establishes a pecking order of guarantors, with British bonds clearly setting the benchmark for all other countries' yield curves. It also reinforces the conclusion we got from factor analysis, in terms of the distinction in the way markets priced guaranteed and non-guaranteed bonds. The former reacted to the cost of credit of the guaranteeing powers, whereas the latter did not - with the exception of the British benchmark. Moreover, with but one exception, the yields on guaranteed bonds also did not react to shocks to the yields of non-guaranteed domestic bonds, further underscoring the separation of the two classes of bonds over the long-run. ${ }^{7}$

The same interpretation is confirmed by decomposing the variance of the individual yield series in Tables A.3-A.6, where British yields dominate among the share of variance explained by foreign powers.

\section{Tables A.3-A.6 here}

The remaining information in the variance decomposition tables confirms the results of the IRFs and of the factor analysis. In all four cases, the variance of the yield of guaranteed bonds reacted more to the yields of the guaranteeing powers than of non-guaranteed bonds. Conversely, the variance of non-guaranteed bonds is hardly explained by the behaviour of the guaranteed bonds and reacts more to domestic developments, although not escaping the impact of changes in the market benchmark, the British consols. Coming back to the Chinese case, Table 11 shows how the variance of the British-German Cassel loan was very dependent on British consol yields. Actually, the formally Russian-guaranteed 4\% loan of 1895 was even more dependent on British yields. The Cassel bonds also reacted slightly less to Russian yields than the guaranteed bond, as expected, although the credit of this guaranteeing power barely explains $6 \%$ of the variance of both loans. This is suggestive, as mentioned previously, of the existence of financial spheres of influence as expressed in bond prices, but it also reveals the smaller relevance of a formal guaranty by a power of dubious credit itself.

\footnotetext{
${ }^{7}$ The exception is the IRFs of the Egyptian 1885 guaranteed bond to the unified debt (Figure 10).
} 
Table A.1: Tests of Dilution

\begin{tabular}{|c|c|c|c|c|c|c|c|c|c|c|c|c|}
\hline & \multicolumn{6}{|c|}{ Event window = 2 days } & \multicolumn{6}{|c|}{ Event window $=$ C.I.s of Bai-Perron breakpoint tests } \\
\hline & \multicolumn{2}{|c|}{15 days } & \multicolumn{2}{|c|}{20 days } & \multicolumn{2}{|c|}{30 days } & \multicolumn{2}{|c|}{15 days } & \multicolumn{2}{|c|}{20 days } & \multicolumn{2}{|c|}{30 days } \\
\hline & before & bilateral & before & bilateral & before & bilateral & before & bilateral & before & bilateral & before & bilateral \\
\hline $\mathrm{J}_{1}$ & $\begin{array}{l}13.688 \\
(0.000)\end{array}$ & $\begin{array}{r}4.439 \\
(0.000)\end{array}$ & $\begin{array}{l}15.306 \\
(0.000)\end{array}$ & $\begin{array}{r}5.271 \\
(0.000)\end{array}$ & $\begin{array}{l}14.604 \\
(0.000)\end{array}$ & $\begin{array}{r}7.317 \\
(0.000)\end{array}$ & $\begin{array}{r}6.223 \\
(0.000)\end{array}$ & $\begin{array}{r}-0.676 \\
(0.125)\end{array}$ & $\begin{array}{r}-0.562 \\
(0.144)\end{array}$ & $\begin{array}{r}-3.246 \\
(0.000)\end{array}$ & $\begin{array}{r}-6.355 \\
(0.000)\end{array}$ & $\begin{array}{r}-6.908 \\
(0.000)\end{array}$ \\
\hline $\mathrm{J}_{2}$ & $\begin{array}{l}48.925 \\
(0.000)\end{array}$ & $\begin{array}{l}19.627 \\
(0.000)\end{array}$ & $\begin{array}{l}71.351 \\
(0.000)\end{array}$ & $\begin{array}{l}24.567 \\
(0.000)\end{array}$ & $\begin{array}{l}54.925 \\
(0.000)\end{array}$ & $\begin{array}{l}21.526 \\
(0.000)\end{array}$ & $\begin{array}{r}-100.920 \\
(0.000)\end{array}$ & $\begin{array}{r}-62.891 \\
(0.000)\end{array}$ & $\begin{array}{r}194.382 \\
(0.000)\end{array}$ & $\begin{array}{r}-94.652 \\
(0.000)\end{array}$ & $\begin{array}{r}238.276 \\
(0.000)\end{array}$ & $\begin{array}{r}-143.167 \\
(0.000)\end{array}$ \\
\hline $\mathrm{J}_{3}$ & $\begin{array}{r}1.265 \\
(0.051)\end{array}$ & $\begin{array}{r}0.632 \\
(0.132)\end{array}$ & $\begin{array}{r}1.897 \\
(0.014)\end{array}$ & $\begin{array}{r}0.632 \\
(0.132)\end{array}$ & $\begin{array}{r}1.265 \\
(0.051)\end{array}$ & $\begin{array}{r}0.632 \\
(0.132)\end{array}$ & $\begin{array}{r}-3.317 \\
(0.000)\end{array}$ & $\begin{array}{r}-5.005 \\
0.00\end{array}$ & $\begin{array}{r}-4.161 \\
(0.000)\end{array}$ & $\begin{array}{r}-5.246 \\
(0.000)\end{array}$ & $\begin{array}{r}-5.367 \\
(0.000)\end{array}$ & $\begin{array}{r}-4.884 \\
(0.000)\end{array}$ \\
\hline $\mathrm{J}_{4}$ & $\begin{array}{r}-3.467 \\
(0.000)\end{array}$ & $\begin{array}{r}-3.467 \\
(0.000)\end{array}$ & $\begin{array}{r}-3.467 \\
(0.000)\end{array}$ & $\begin{array}{r}-3.467 \\
(0.000)\end{array}$ & $\begin{array}{r}-3.467 \\
(0.000)\end{array}$ & $\begin{array}{r}-3.467 \\
(0.000)\end{array}$ & $\begin{array}{r}1.992 \\
(0.012)\end{array}$ & $\begin{array}{r}1.992 \\
(0.012)\end{array}$ & $\begin{array}{r}1.989 \\
(0.012)\end{array}$ & $\begin{array}{r}1.989 \\
(0.012)\end{array}$ & $\begin{array}{r}1.992 \\
(0.012)\end{array}$ & $\begin{array}{r}1.992 \\
(0.012)\end{array}$ \\
\hline $\mathrm{J}_{1 c s}$ & $\begin{array}{l}30.353 \\
(0.000)\end{array}$ & $\begin{array}{l}32.472 \\
(0.000)\end{array}$ & $\begin{array}{l}39.691 \\
(0.000)\end{array}$ & $\begin{array}{l}31.105 \\
(0.000)\end{array}$ & $\begin{array}{l}52.520 \\
(0.000)\end{array}$ & $\begin{array}{l}39.811 \\
(0.000)\end{array}$ & $\begin{array}{r}1.610 \\
(0.027)\end{array}$ & $\begin{array}{r}-0.370 \\
(0.178)\end{array}$ & $\begin{array}{r}-0.150 \\
(0.220)\end{array}$ & $\begin{array}{l}-1.643 \\
(0.025)\end{array}$ & $\begin{array}{r}-1.331 \\
(0.046)\end{array}$ & $\begin{array}{r}-3.205 \\
(0.000)\end{array}$ \\
\hline$J_{2 c s}$ & $\begin{array}{l}12.145 \\
(0.000)\end{array}$ & $\begin{array}{r}9.440 \\
(0.000)\end{array}$ & $\begin{array}{l}14.394 \\
(0.000)\end{array}$ & $\begin{array}{r}9.514 \\
(0.000)\end{array}$ & $\begin{array}{l}11.185 \\
(0.000)\end{array}$ & $\begin{array}{l}16.535 \\
(0.000)\end{array}$ & $\begin{array}{r}-1.310 \\
(0.048)\end{array}$ & $\begin{array}{r}-2.199 \\
(0.007)\end{array}$ & $\begin{array}{r}2.382 \\
(0.004)\end{array}$ & $\begin{array}{r}-3.282 \\
(0.000)\end{array}$ & $\begin{array}{r}2.365 \\
(0.005)\end{array}$ & $\begin{array}{r}-4.660 \\
(0.000)\end{array}$ \\
\hline
\end{tabular}


Table A.2: GMM estimates of Panel VAR

\begin{tabular}{|c|c|c|c|c|c|c|c|}
\hline & & ygbr & yfra & yrus & $y_{g}$ & $Y_{01}$ & $Y_{02}$ \\
\hline \multirow[t]{4}{*}{$\begin{array}{l}\text { Turkey } \\
(\mathrm{N}=870)\end{array}$} & ygbr & $\begin{array}{l}0.9696 * * * \\
(0.0108)\end{array}$ & $\begin{array}{l}0.0317^{* *} \\
(0.0159)\end{array}$ & & $\begin{array}{l}-0.0228 \\
(0.0165)\end{array}$ & $\begin{array}{l}0.0007 \\
(0.0012)\end{array}$ & \\
\hline & yfra & $\begin{array}{l}0.0214 \\
(0.0271)\end{array}$ & $\begin{array}{l}0.9864^{* * *} \\
(0.0662)\end{array}$ & & $\begin{array}{l}-0.0743 \\
(0.0736)\end{array}$ & $\begin{array}{l}-0.0272 \\
(0.0050)\end{array}$ & 0.0017 \\
\hline & y1855 & $\begin{array}{l}-0.0427 \\
(0.0533)\end{array}$ & $\begin{array}{l}-0.0067 \\
(0.1570)\end{array}$ & & $\begin{array}{l}1.013 * * * \\
(0.1719)\end{array}$ & $\begin{array}{l}0.0022 \\
(0.0099)\end{array}$ & \\
\hline & y1854 & $\begin{array}{l}-0.1176 \\
(0.4806)\end{array}$ & $\begin{array}{l}0.2960 \\
(1.3632)\end{array}$ & & $\begin{array}{l}-0.0656 \\
(1.5048)\end{array}$ & $\begin{array}{l}0.9333^{* * *} \\
(0.1049)\end{array}$ & \\
\hline \multirow[t]{5}{*}{$\begin{array}{l}\text { Egypt } \\
\text { ( } N=842)\end{array}$} & ygbr & $\begin{array}{l}0.8852^{* * *} \\
(0.1070)\end{array}$ & $\begin{array}{l}0.0017 \\
(0.0316)\end{array}$ & & $\begin{array}{l}0.1704 \\
(0.2046)\end{array}$ & $\begin{array}{l}0.0092 \\
(0.0432)\end{array}$ & $\begin{array}{l}0.0033 \\
(0.0151)\end{array}$ \\
\hline & yfra & $\begin{array}{l}-0.1028 \\
(0.1050)\end{array}$ & $\begin{array}{l}0.8373 * * * \\
(0.0837)\end{array}$ & & $\begin{array}{l}0.2221 \\
(0.2174)\end{array}$ & $\begin{array}{l}0.2685 \\
(0.0467)\end{array}$ & $\begin{array}{l}0.0163 \\
(0.0432)\end{array}$ \\
\hline & y1885 & $\begin{array}{l}0.0491 \\
(0.1079)\end{array}$ & $\begin{array}{l}0.0971^{* *} \\
(0.0464)\end{array}$ & & $\begin{array}{l}0.958 * * * \\
(0.2052)\end{array}$ & $\begin{array}{l}0.0435 \\
(0.0451)\end{array}$ & $\begin{array}{l}-0.0721 \\
(0.0234)\end{array}$ \\
\hline & ystate & $\begin{array}{l}-0.1360 \\
(0.1069)\end{array}$ & $\begin{array}{l}-0.0149 \\
(0.0678)\end{array}$ & & $\begin{array}{l}0.1770 \\
(0.2008)\end{array}$ & $\begin{array}{l}0.9172 * * * \\
(0.0651)\end{array}$ & $\begin{array}{l}0.0746 \\
(0.0520)\end{array}$ \\
\hline & yunif & $\begin{array}{l}0.0151 \\
(0.1056)\end{array}$ & $\begin{array}{l}0.0770 \\
(0.0405) \\
\end{array}$ & & $\begin{array}{l}0.0278 \\
(0.2056)\end{array}$ & $\begin{array}{l}0.0771 \\
(0.0477) \\
\end{array}$ & $\begin{array}{l}0.8785^{* * *} \\
(0.0369)\end{array}$ \\
\hline \multirow[t]{4}{*}{$\begin{array}{l}\text { China } \\
(\mathrm{N}=515)\end{array}$} & ygbr & $\begin{array}{l}0.9883^{* * *} \\
(0.0308)\end{array}$ & (0.0093) & $\begin{array}{l}0.0092 \\
(0.0280)\end{array}$ & $\begin{array}{l}-0.0091 \\
(0.0378)\end{array}$ & $\begin{array}{l}0.0049 \\
(0.0783)\end{array}$ & \\
\hline & yrus & $\begin{array}{l}-0.0564 \\
(0.0753)\end{array}$ & $\begin{array}{l}0.9777^{* * *} \\
(0.0463)\end{array}$ & $\begin{array}{l}0.0753 \\
(0.0568)\end{array}$ & $\begin{array}{l}-0.0084 \\
(0.0525)\end{array}$ & $\begin{array}{l}-0.0147 \\
(0.1694)\end{array}$ & \\
\hline & y1895 & $\begin{array}{l}0.0948 \\
(0.0624)\end{array}$ & $\begin{array}{l}0.0357^{*} \\
(0.0225)\end{array}$ & $\begin{array}{l}0.8141 * * * \\
(0.0592)\end{array}$ & $\begin{array}{l}0.0511 \\
(0.0436)\end{array}$ & $\begin{array}{l}0.1298 * \\
(0.0767)\end{array}$ & \\
\hline & ycassel & $\begin{array}{l}-0.0833 \\
(0.1114)\end{array}$ & $\begin{array}{l}-0.0208 \\
(0.0697)\end{array}$ & $\begin{array}{l}0.1679 \\
(0.1086)\end{array}$ & $\begin{array}{l}0.9213^{* * *} \\
(0.0873)\end{array}$ & $\begin{array}{l}0.7714^{* * *} \\
(0.1294)\end{array}$ & \\
\hline \multirow[t]{6}{*}{$\begin{array}{l}\text { Greece } \\
(\mathrm{N}=428)\end{array}$} & ygbr & $\begin{array}{l}0.9310^{* * *} \\
(0.0690)\end{array}$ & $\begin{array}{l}0.0141 \\
(0.0592)\end{array}$ & $\begin{array}{l}0.0070 \\
(0.0204)\end{array}$ & $\begin{array}{l}0.0307 \\
(0.1226)\end{array}$ & $\begin{array}{l}0.0593 \\
(0.0936)\end{array}$ & $\begin{array}{l}-0.0585 \\
(0.0880)\end{array}$ \\
\hline & yfra & $\begin{array}{l}0.0306 \\
(0.0341)\end{array}$ & $\begin{array}{l}1.0145^{* * *} \\
(0.0341)\end{array}$ & $\begin{array}{l}0.0002 \\
(0.0173)\end{array}$ & $\begin{array}{l}-0.0587 \\
(0.0550)\end{array}$ & $\begin{array}{l}-0.0968 \\
(0.0692)\end{array}$ & $\begin{array}{l}0.0944 \\
(0.0661)\end{array}$ \\
\hline & yrus & $\begin{array}{l}-0.1970 \\
(0.1301)\end{array}$ & $\begin{array}{l}-0.1769 \\
(0.1370)\end{array}$ & $\begin{array}{l}0.9802 * * * \\
(0.0668)\end{array}$ & $\begin{array}{l}0.3765 \\
(0.2475)\end{array}$ & $\begin{array}{l}-0.0965 \\
(0.2568)\end{array}$ & $\begin{array}{l}0.0938 \\
(0.2396)\end{array}$ \\
\hline & y1898 & $\begin{array}{l}0.1877^{* * *} \\
(0.0447)\end{array}$ & $\begin{array}{l}0.1829 * * * \\
(0.0474)\end{array}$ & $\begin{array}{l}0.0426^{* * *} \\
(0.0212)\end{array}$ & $\begin{array}{l}0.5506^{* * *} \\
(0.0720)\end{array}$ & $\begin{array}{l}0.0250 \\
(0.0994)\end{array}$ & $\begin{array}{l}-0.0058 \\
(0.0968)\end{array}$ \\
\hline & y1881 & $\begin{array}{l}0.0123 \\
(0.1536)\end{array}$ & $\begin{array}{l}-0.0696 \\
(0.1781)\end{array}$ & $\begin{array}{l}-0.0530 \\
(0.0645)\end{array}$ & $\begin{array}{l}0.1266 \\
(0.3174)\end{array}$ & $\begin{array}{l}0.3465 \\
(0.3808)\end{array}$ & $\begin{array}{l}0.6192 * \\
(0.3726)\end{array}$ \\
\hline & y1884 & $\begin{array}{l}0.0019 \\
(0.1527)\end{array}$ & $\begin{array}{l}-0.0037 \\
(0.1715)\end{array}$ & $\begin{array}{l}-0.0049 \\
(0.0634)\end{array}$ & $\begin{array}{l}0.0110 \\
(0.3092)\end{array}$ & $\begin{array}{l}0.0220 \\
(0.3866)\end{array}$ & $\begin{array}{l}0.9550 * * \\
(0.3802)\end{array}$ \\
\hline
\end{tabular}

$\mathrm{y}_{\mathrm{g}}$ represents the yields of the guaranteed bonds in each case; $\mathrm{y}_{\mathrm{o} 1}$ and $\mathrm{y}_{\mathrm{o} 2}$ stand for the first and second nonguaranteed bond in each case. Standard errors in parenthesis. ${ }^{* *},{ }^{* *}$ and ${ }^{*}$ denote significant coefficients, respectively at the 1,5 and $10 \%$ confidence levels. 
Table A.3: Variance decomposition of Turkish bonds

\begin{tabular}{lllll}
\hline & ygbr & yfra & y1855 & y1854 \\
\hline \hline ygbr & 0.9083 & 0.0210 & 0.0695 & 0.0013 \\
yfra & 0.5033 & 0.4321 & 0.0602 & 0.0044 \\
y1855 & 0.0658 & 0.0016 & 0.9296 & 0.0030 \\
y1854 & 0.0233 & 0.0362 & 0.0047 & 0.9359
\end{tabular}

Decomposition for 10 periods ahead.

Table A.4: Variance decomposition of Egyptian bonds

\begin{tabular}{llllll}
\hline & ygbr & yfra & y1885 & ystate & yunif \\
\hline ygbr & 0.8804 & 0.0253 & 0.0888 & 0.0039 & 0.0016 \\
yfra & 0.6663 & 0.1946 & 0.1253 & 0.0131 & 0.0006 \\
y1885 & 0.7269 & 0.0616 & 0.1975 & 0.0067 & 0.0073 \\
ystate & 0.4593 & 0.0556 & 0.1166 & 0.3643 & 0.0043 \\
yunif & 0.6791 & 0.1066 & 0.0617 & 0.0662 & 0.0865 \\
\hline
\end{tabular}

Decomposition for 10 periods ahead.

Table A.5: Variance decomposition of Chinese bonds

\begin{tabular}{lllll}
\hline & ygbr & yrus & y1895 & ycassel \\
\hline \hline ygbr & 0.9983 & 0.0011 & 0.0001 & 0.0004 \\
yrus & 0.5150 & 0.4637 & 0.0212 & 0.0001 \\
y1895 & 0.7469 & 0.0611 & 0.1664 & 0.0256 \\
ycassel & 0.3964 & 0.0601 & 0.0526 & 0.4908 \\
\hline
\end{tabular}

Decomposition for 10 periods ahead.

Table A.6: Variance decomposition of Greek bonds

\begin{tabular}{lllllll}
\hline & ygbr & yfra & yrus & y1898 & y1881 & y1884 \\
\hline \hline ygbr & 0.9959 & 0.0029 & 0.0006 & 0.0004 & 0.0000 & 0.0002 \\
yfra & 0.8766 & 0.1202 & 0.0000 & 0.0014 & 0.0005 & 0.0013 \\
yrus & 0.5079 & 0.0490 & 0.4069 & 0.0342 & 0.0010 & 0.0010 \\
y1898 & 0.9368 & 0.0397 & 0.0062 & 0.0163 & 0.0007 & 0.0003 \\
y1881 & 0.6142 & 0.0003 & 0.0004 & 0.0064 & 0.3514 & 0.0272 \\
y1884 & 0.6058 & 0.0000 & 0.0019 & 0.0061 & 0.3484 & 0.0378 \\
\hline
\end{tabular}

Decomposition for 10 periods ahead. 
Figure A.1: Alternative yields of Egyptian 3\% guaranteed bond of 1885

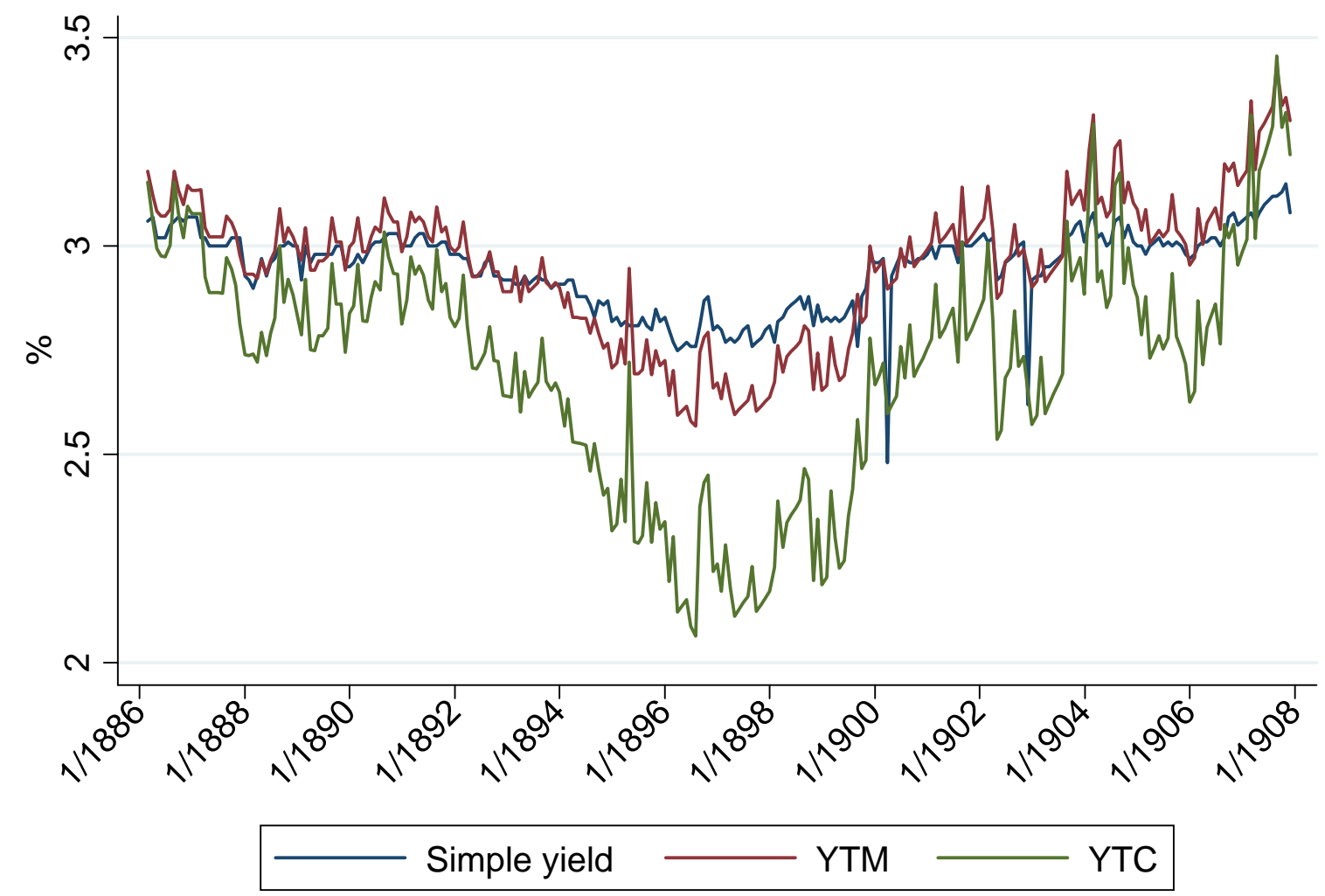

Monthly data. Source: IMM.

Figure A.2: Impulse Response Functions for Turkey 1855
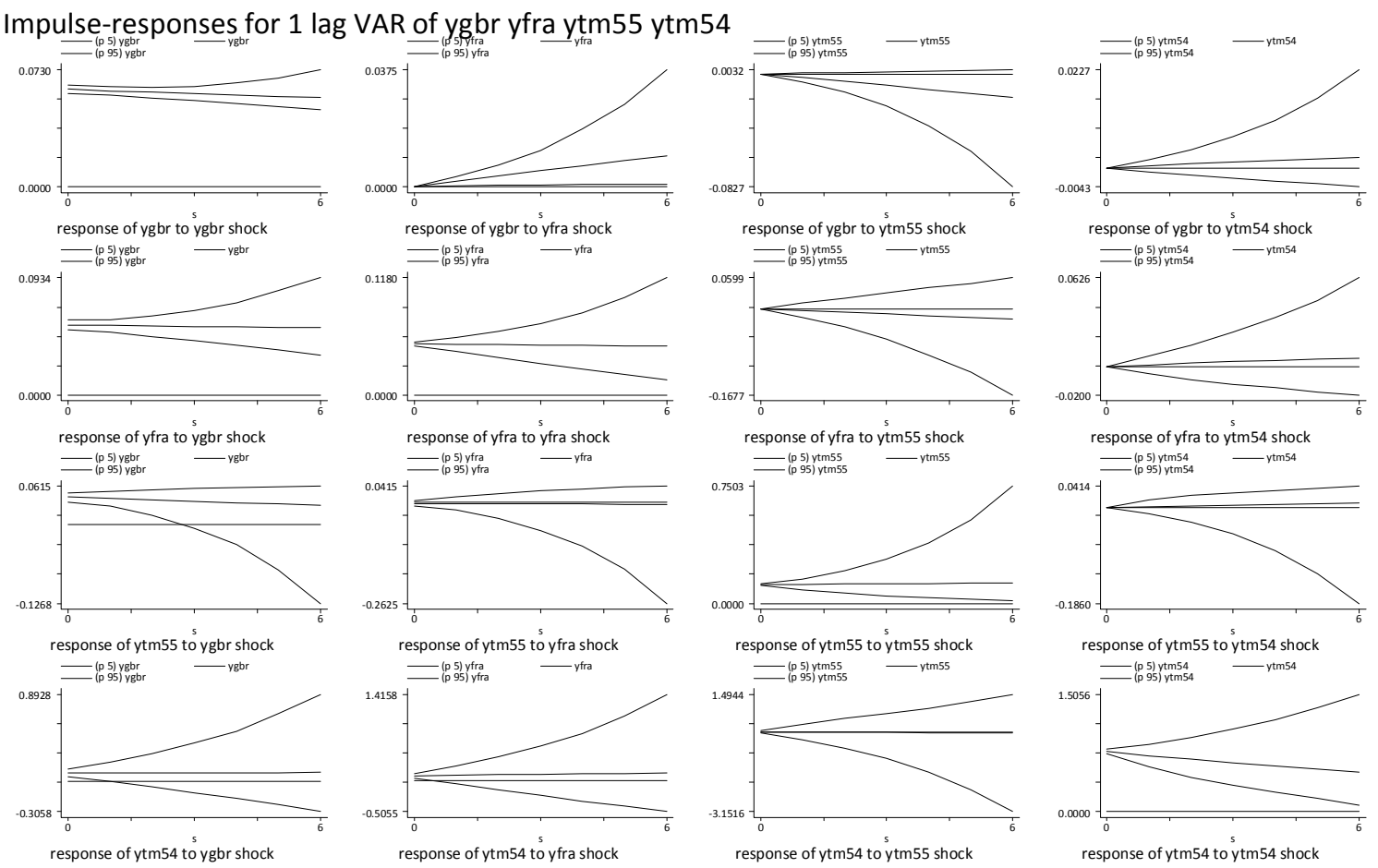

Errors are $5 \%$ on each side generated by Monte-Carlo with 500 reps 
Figure A.3: Impulse Response Functions for Egypt 1885

Impulse-responses for 1 lag VAR of ygbr yfra ytm8 8 ytmstate yunif
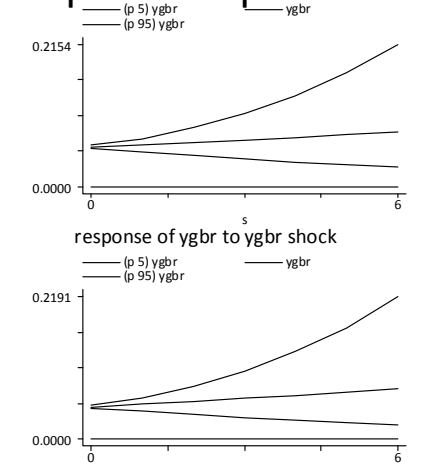

0.0000

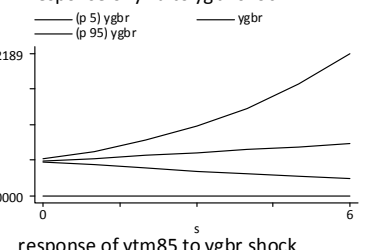

response of ytm85 to ygbr shock

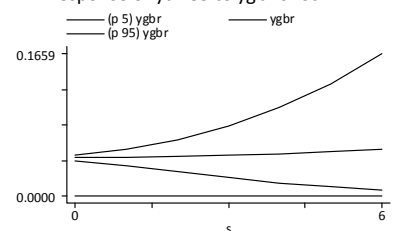

response of ytmstate to ygbr shock

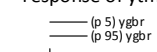

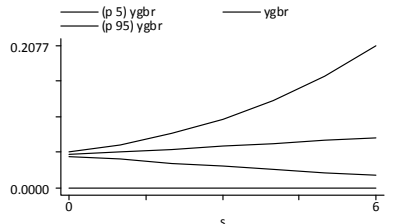

response of yunif to ygbr shock

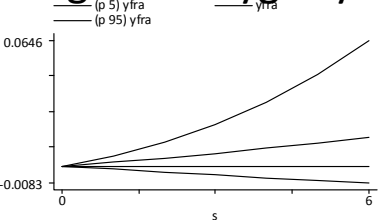

response of ygbr to yfra shock
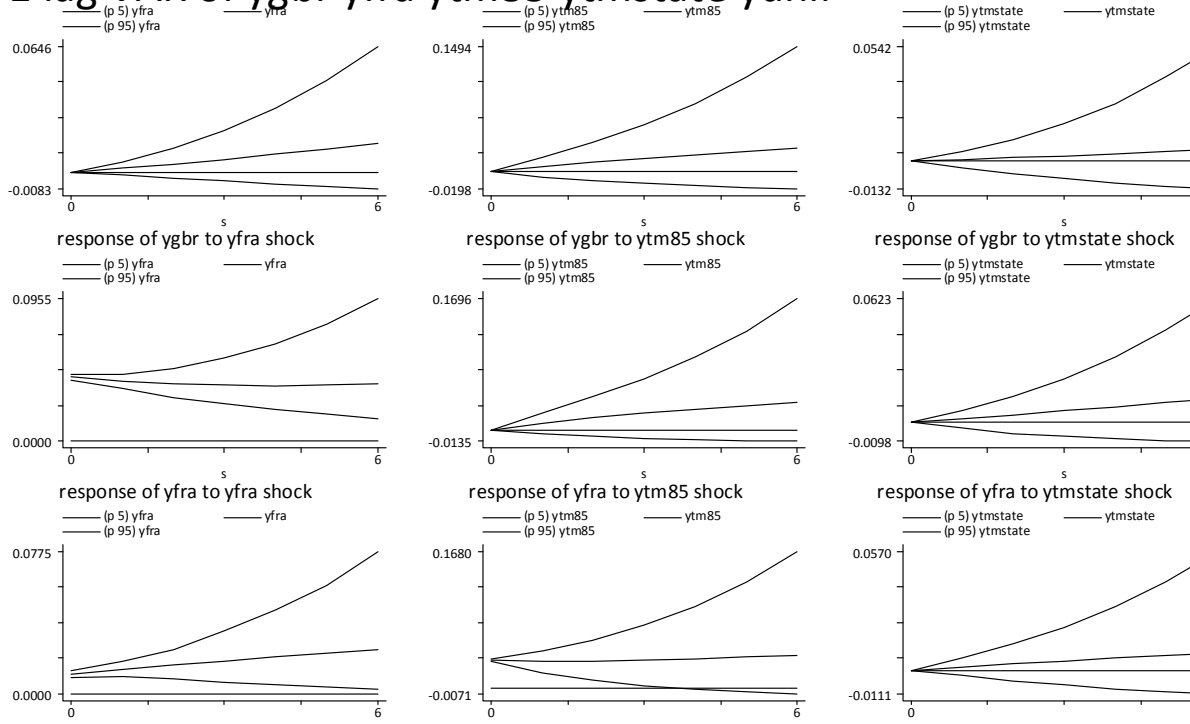

response of ytm 85 to yfra shock

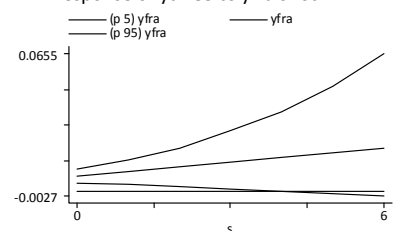

response of ytmstate to yfra shock

三

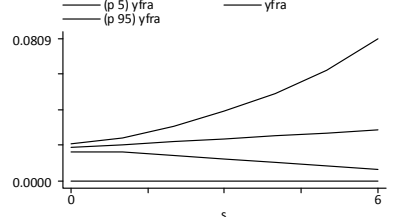

response of yunif to yfra shock
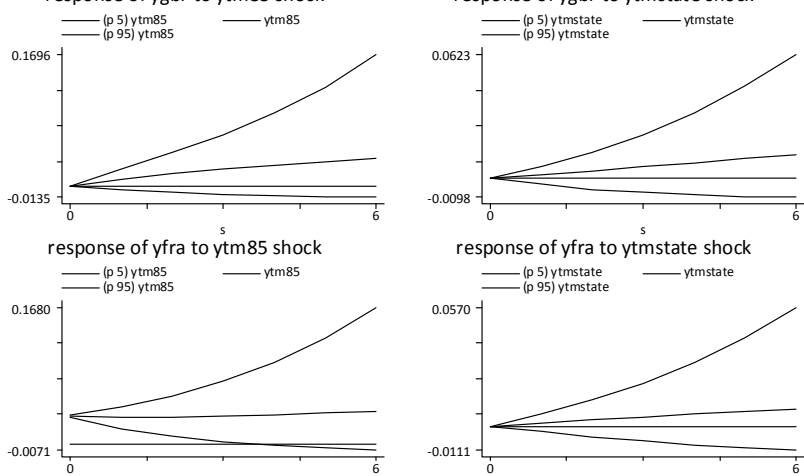

response of yfra to ytmstate shock

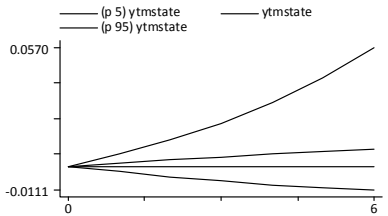

response of ytm 85 to ytm 85 shock

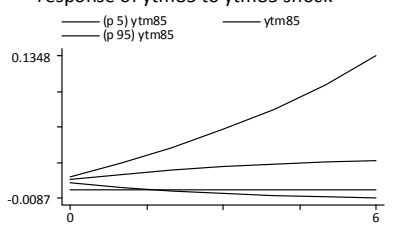

response of ytmstate to ytm 85 shock

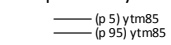

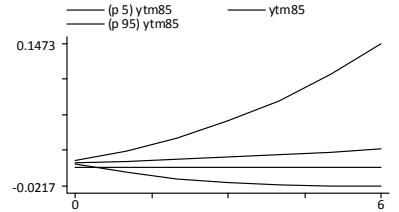

response of yunif to ${ }^{\varsigma} \mathrm{tm} 85$ shock

response of ytm 85 to ytmstate shock $^{\mathrm{s}}$

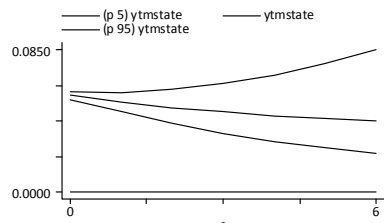

response of ytmstate to ytmstate shock

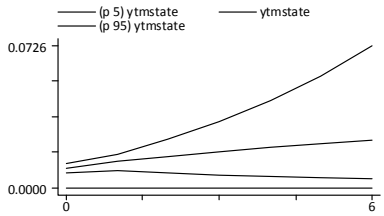

response of yunif to ytmstate shock
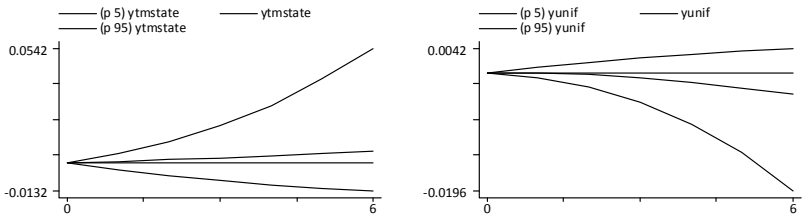

response of ygbr to yunif shock

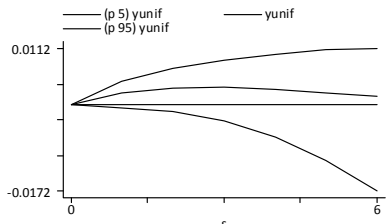

response of yfra to yunif shock

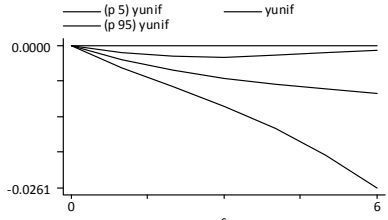

\section{response of ytm85 to yunif shock}

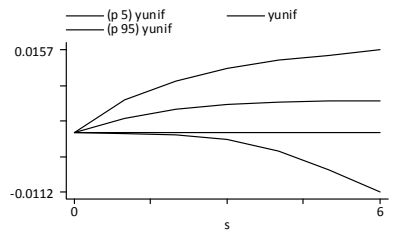

response of ytmstate to yunif shock

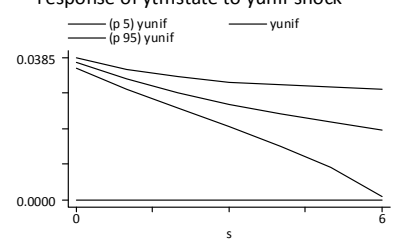

response of yunif to yunif shock

Errors are $5 \%$ on each side generated by Monte-Carlo with 500 reps 
Figure A.4: Impulse Response Functions for Greece 1898

Impulse-responses for 1 lag VAR of ygbr yfra yrus ytm98 ytm 1 in 1 ytm 84
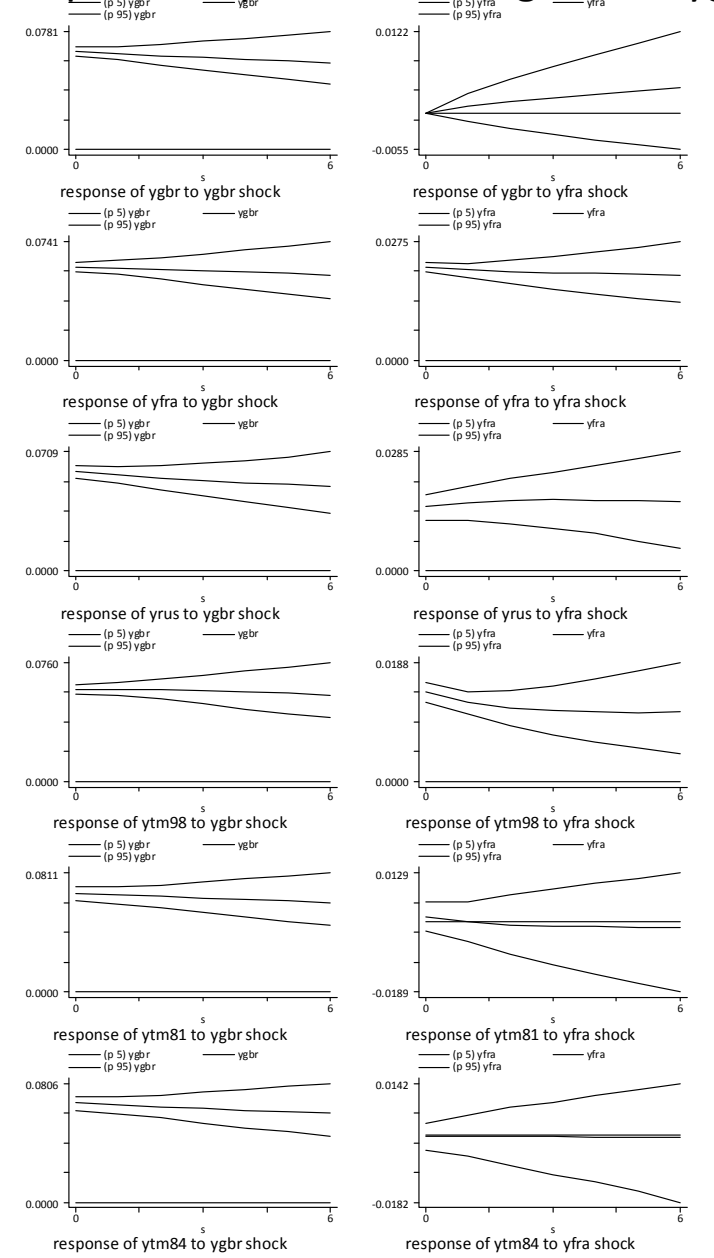

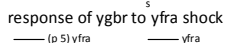

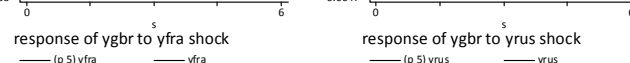

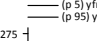

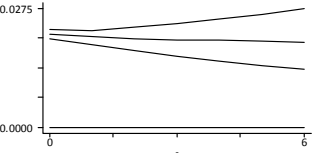

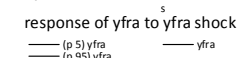
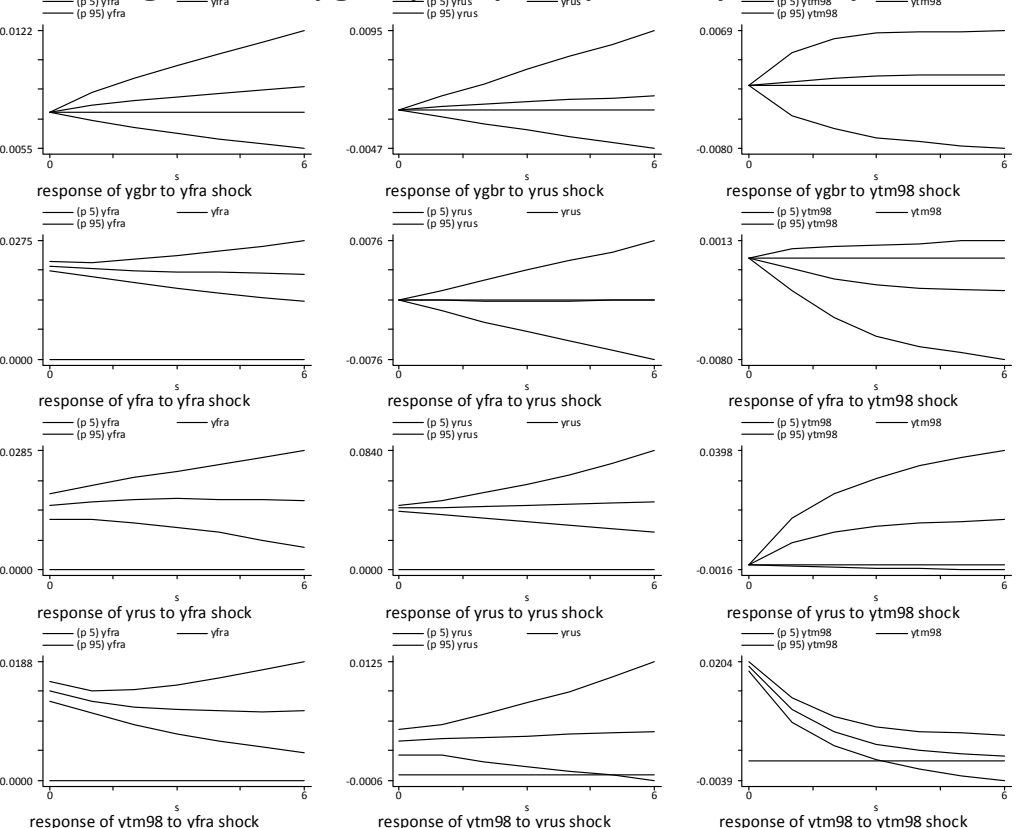

response of ytm98 to yfra shock
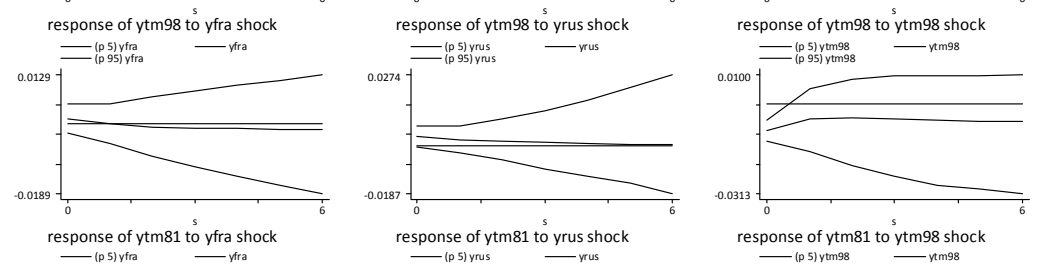

response of ytm81 to yfra sho
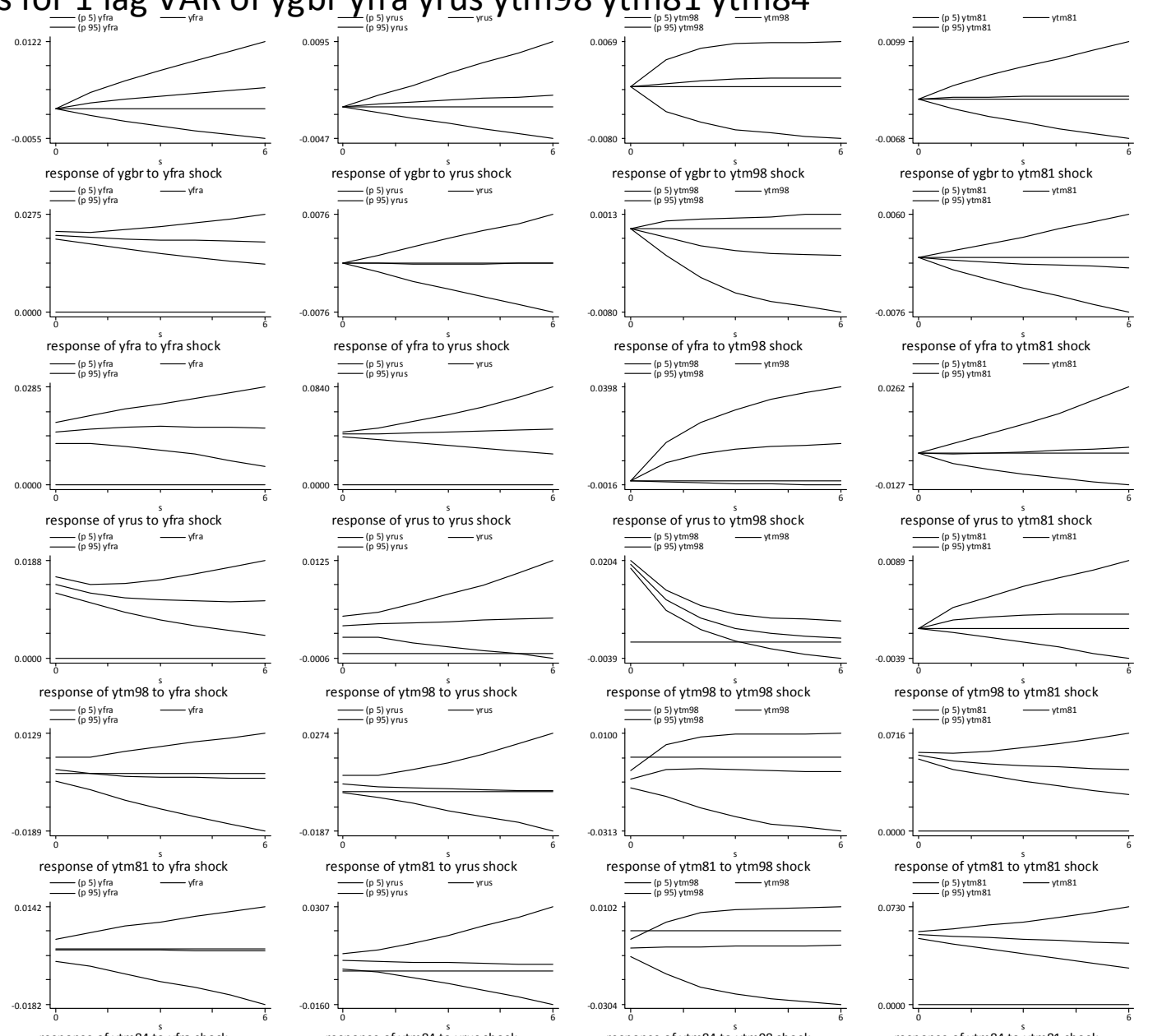

response of ytm 84 to yfra shock

response of ytm84 to yrus shock

response of ytm84 to ytm98 shock

response of ytm84 to ${ }^{5}$ tm 81 shock

Errors are $5 \%$ on each side generated by Monte-Carlo with 500 reps
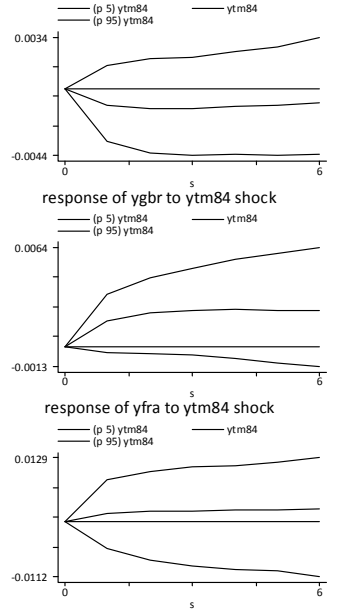

response of yrus to ytm84 shock
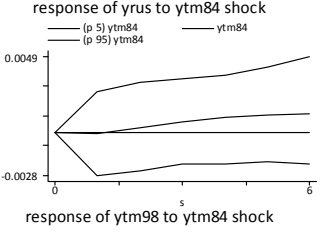

response of ytm98 to ytm84 shock

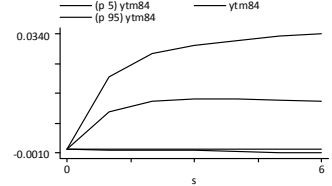

response of ytm81 to ytm84 shock

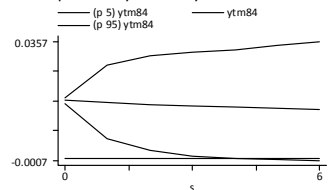

response of ytm84 to ytm84 shock 
Figure A.5: Impulse Response Functions for China 1895

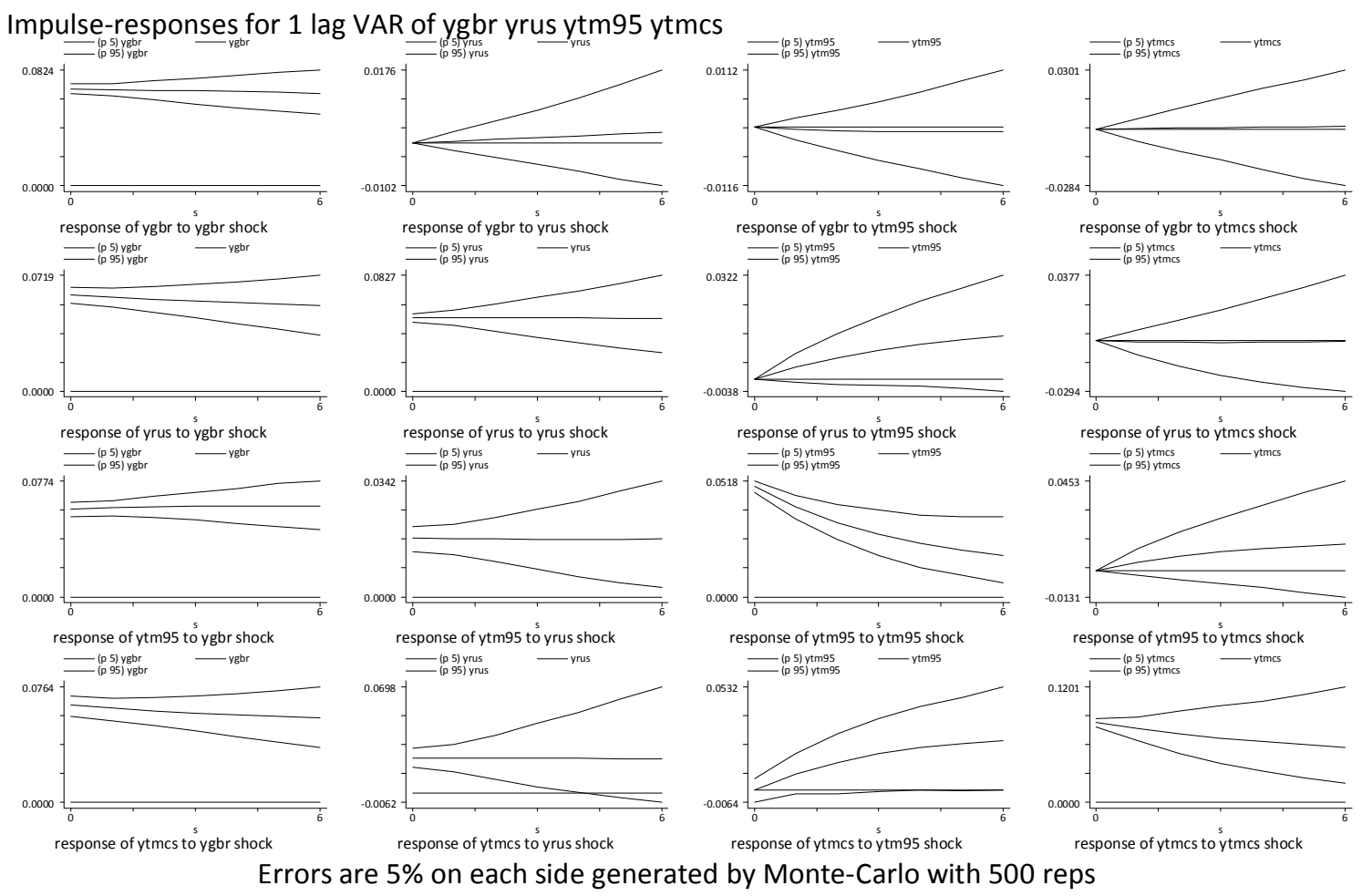

\section{A.4. References}

Arellano, M. and S. Bond. (1991) "Some tests of specification for panel data: Monte Carlo evidence and an application to employment equations," Review of Economic Studies, 58(2): 277-297.

Arellano, M. and O. Bover (1995) "Another look at the instrumental variable estimation error component models," Journal of Econometrics, 68(10): 29-51.

Campbell, J., A. Lo and A. MacKinlay (1997) The Econometrics of Financial Markets, Princeton: Princeton University Press.

Choi, I. (2001) "Unit root tests for panel data," Journal of International Money and Finance, 20: 249272.

Eichengreen, B. and A. Mody (2000) "Lending Booms, Reserves, and the Sustainability of Short-Term Debt: Inferences from the Pricing of Syndicated Bank Loans," Journal of Development Economics, 63(1): 5-44.

Flandreau, M. And F. Zumer (2004) The Making of Global Finance, 1880-1913, Paris: OECD.

Uribe, M. and V. Yue (2006) "Country Spreads and Emerging Countries: Who Drives Whom?" Journal of International Economics 69(1): 6-36. 